\title{
SIGNIFICANCE OF INHERITED SOIL PEDOGENIC ASPECTS AS RELATED TO SOME NUTRIENTS STATUS IN BOTH SOILS AND GROWN PLANTS AT EL FAYOUM AREA, EGYPT
}

\author{
Abdel Nasser A.A. Abdel Hafeez*, Mohsen A. M. EI Bassiouny and \\ Hamed A. Awadalla \\ *Soils and Water Department, Fac. of Agric., Fayoum University, Egypt. \\ Soils, Water and Environment Res. Inst., Agric. Res. Center, Giza, Egypt
}

\section{ABSTRACT:}

In the current study, a special attention was focused to identify the inherited soil pedogenic aspects in a selected area of El-Fayoum district, Egypt, which were achieved through the different cyclic-sequences of soil formation by using the obtained data from Enhanced Images of Landsat Thematic Mapper 7 of the bands 2, 3 and 4 (ETM7, 2005), which are processed within the geographic software. Such step represents a base for assessing the soil potentiality for essential plant nutrients, and in turn the sustainable agriculture on the long-term. The second attention was focused for setting up database of wheat yield and its components as an indicator plant, through studying the growth parameters/plant at vegetative stage (i.e., height, dry weight, tiller number, leaf area, chlorophyll a \& b and nutrients uptake), biological yield and grain quality at harvest stage (i.e., spike characters, weight of 1000 grain, grain or straw yields/fed as well as grain content of protein, carbohydrates, sugars and amino acids) as affected by the studied soil properties (i.e., texture grade, bulk density, available water, $\mathrm{CaCO}_{3}$, organic matter, ESP, $\mathrm{pH}$ and $\mathrm{ECe}$ ) under different cyclic-sequences of the deposited soil constituents. Such possible relationships are usually used as a guide to explain and correct the problems facing the current and future agricultural utilization projects, particularly fertilization policy. Consequently, proposing the best landuse whether be under demand for agricultural purposes or be planned for later on.

The obtained results showed that the identified soil characteristics of the studied area are markedly varied and depending upon the soil genesis status. Consequently, the essential plant nutrient contents of the soil, either in total or available forms, as related to soil genesis and main characteristics were exhibited widely variations. Hence, building a geographic database for the main soil characteristics was established by using ILWIS software within CIS format. On the other hand, the statistical analyses, i.e., simple correlation coefficients, multiple regression equations and stepwise, were distinguished by aiding the program outlined by SPSS (2003) software for assessing the different relationships between the studied soil variables and plant nutrients whether as total and available contents. Moreover, the contribution percentages of either soil constituents with the studied total nutrient contents or the studied soil variables with the available nutrient fractions were defined.

The positive or negative reflections of the aforementioned soil relationships on the plant parameters of grown wheat (Sakha $93 \mathrm{cv}$.) at both vegetative growth and harvest stages during an agricultural growing winter season of 2009/2010 for selected nine soil sites were also taken into consideration in this study. The results obtained indicate that such soil relationships are exerted a great beneficial effect on the studied plant parameters at both growth and harvest stages of wheat crop in soil characterized by best soil variables, that having a pronounced content of nutrient-bearing minerals as well as factors that are enhancing more released

Fayoum J. Agric. Res. \& Dev., Vol.24, No.2, July, 2010 
nutrients and their solubilization from both sources of native or added as well the favourable biological conditions that are keeping them in available forms for extended period and their mobility for uptake by plant roots. The reverse was true for soils have adverse soil variables, particularly those are poorer in nutrient-bearing minerals and exhibited adverseable conditions that are controlling released nutrients and their availability for uptake by plant roots.

Key words: El-Fayoum soils, Nutrients status, thematic maps, wheat crop, inherited soil pedogenic aspects.

\section{INTRODUCTION:}

Soils of El Fayoum depression are derived and developed on different origins, i.e., the Nile alluvium, lacustrine and desert formations of calcareous or siliceous in nature, beside the interference zones between these sediments. So, the nutritional problems in such soils are related not only to the adverse environmental conditions of such an arid region that lead to nutrients deficiency, but also to the wide variations in the nature of the prevailing soil sediments. Thus, identifying more information about the nature of these soil sediments must be carried out, particularly those concerned with nutrient bearing minerals. This will be useful as a guide for successful fertilization system, and in turn it is of vita importance for agricultural utilization programs in El Fayoum Governorate (Abdel Hafeez et al., 2008). In that concern, there are several factors govern the nature of the various nutrient forms derived from the different resources, i.e., a) the character of the composition of the bed-rock or pseudo-eroded soil-mass which depends on the environmental conditions, b) the texture of the soil material, c) the degree of pre-weathering of the parent material and d) duration of both soil formation and the water regime cycles. At the same-time, all these characteristics, that influence directly or indirectly the availability of nutrients for plant, are more related with the vegetative growth and consequently the economic crop yield. Hence, the factors affecting them always acquire the scientific attention of many investigators (Lindsay, 1972 and Ibrahim, 2001), as follows.

Nitrogen movement has a marked influence on the quantity of nitrogen present in the soil at any time and in turn its availability to crop plants. This generally has a transient existence in soil as it is readily hydrolyzed. Rolston $\boldsymbol{e t}$ al. (1979) reported that leaching of ammonium from soils depended upon the soil texture and rat of $\mathrm{NH}_{4}{ }^{+}$application. Awadalla (1993) found that the total amounts of $\mathrm{N}$ ranged $506.00-733.60 \mathrm{mg} \mathrm{kg}^{-1}$ in the topsoil of El Fayoum area, and its content tends to decrease with depth $\left(215.00-580.40 \mathrm{mg} \mathrm{kg}^{-1}\right)$. That means these soils are relatively poor in total nitrogen, and $\mathrm{N}$-variations are more attributed to the differences in organic matter content and the microorganisms activity throughout the soil profile. Abd El-Latif (2005) studied the available nitrogen content in El Fayoum soils and pointed out that available nitrogen ranged 43.75$298.95 \mathrm{mg} \mathrm{kg}^{-1}$ soil.

Abbas et al. (2003) reported that the wide range of nutrient contents are apparently associated with soil texture, which are probably dependent on type of parent materials from which the soil was derived or formed. It is worthy to note that the dominant pool of mineral soil $\mathrm{P}$ occurred in either Ca-bound forms of $\mathrm{P}$ in arid and semi-arid regions (Lajtha and Bloomer, 1988) or the poorly crystalline Fe phase and the soil clay fraction (Manu et al., 1991). Awadalla (1993) suggested that $\mathrm{P}$ supply seemed to be of low content in El Fayoum area due to the relatively high $\mathrm{CaCO}_{3}$ content. Leinweber et al. (1997) demonstrated that the

Fayoum J. Agric. Res. \& Dev., Vol.24, No.2, July, 2010 
SIGNIFICANCE OF INHERITED SOIL PEDOGENIC ASPECTS .... 40

clay size separates had the highest $\mathrm{P}$ contents and are particularly enriched in exchangeable and labile forms. Ibrahim (2001) studied the relationship between soil origin and total $\mathrm{P}$ amounts in El Fayoum area, and reported that the total $\mathrm{P}$ was, in general, relatively high in the surface layers of the studied soil sites, indicating it is derived more from an organic source. Also, the magnitude pattern of total $\mathrm{P}$ as related to the studied soil sediments could be categorized into an ascending order of aeolian $\left(187-216 \mathrm{mg} \mathrm{kg}^{-1}\right)<$ old lacustrine $<$ recent lacustrine $>$ fluvio-lacustrine $<$ the Nile alluvial sediment $\left(712-902 \mathrm{mg} \mathrm{kg}^{-1}\right)$. On the other side, available content of $\mathrm{P}$ did not exceed $5 \%$ of the total content (4.6-23.3 mg $\mathrm{kg}^{-1}$ ) and its distribution pattern in the main soil sediments exhibited almost similar trend to those of total content. The relatively available $\mathrm{P}$ content is more attributed to either the high adsorption and/or precipitation with $\mathrm{CaCO}_{3}, \mathrm{MnO}_{2}$ or iron oxides. Abd El-Latif (2005) found that available P varies between 0.23 and $45.0 \mathrm{mg} \mathrm{kg}^{-1}$ soil in El-Fayoum area. Kamel (2006) studied P status in the soils of El-Fayoum Governorate, and found that its content is more related to soil characteristics,i.e., soil texture, $\mathrm{CaCO}_{3}$ content and organic matter content, which are resulted in a wide range of $120-720 \mathrm{mg} \mathrm{kg}^{-1}$. Also, the obtained data of Pavailable fraction extractable ranged between 1.0 and $6.4 \mathrm{mg} \mathrm{kg}^{-1}$ soil.

$\mathrm{K}$ contents in the majority of soils at Egypt were originated from the primary minerals such as the potash feldspars, micas and biotite (Assal, 1981). It is also found in the secondary minerals, i.e., clays of illite and vermiculite. In general, the mineral $\mathrm{K}$ constitutes about $99 \%$ of the total potassium in soil, and about $95 \%$ of $\mathrm{K}$ is within the crystal lattices of the silicate minerals (Abd El Hamid, 1983). Awadalla (1993) showed that soil sediments of El Fayoum region are rich in K, except for the desert formations. Also, Abd EL-Latif (2005) reported that El-Fayoum soils are characterized by the $\mathrm{K}$ enrich Nile alluvial sediments, while the desert and old lacustrine ones are K-poorer sediments.

Basyouny (2005) reported that the recently cultivated soils of Egypt contain low total and available micronutrient contents, may be due to scarcity of organic matter as well as most of these soils are calcareous and sandy in texture. Iron is one of the major constituents of the lithosphere, which contains approximately 5 $\%$ iron. El Shazly et al. (1991) pointed out that $\mathrm{Fe}$ was positively and significantly correlated with most soil variables of clay, (clay + silt) and organic matter, while it was significantly and negatively correlated with $\mathrm{CaCO}_{3}$. Awadalla (1993) found that the highest amount of $\mathrm{Fe}$ in El-Fayoum soils was associated with the Nile alluvial soils, while the lowest one was found in the desert soils. Also, the available Fe constitutes a small pool of the total content and being in the range of 3.02 to $23.43 \mathrm{mg} / \mathrm{kg}$. Kamh et al. (1995) showed that the soil under saturation conditions generally increased $\mathrm{Fe}$ forms of soluble, exchangeable, complexes and crystalline iron oxides. Zhang et al. (1997) found that greater than 60 and $80 \%$ of total $\mathrm{Fe}$ was present in the amorphous and crystalline Fe oxide forms in soils, respectively. El-Sowfy (2004) found that total Fe values in soils varied in their characteristics at El-Fayoum ranged between 0.67 and $2.93 \%$. As for the available Fe extracted with DTPA, its values ranged 0.30$9.42 \mathrm{mg} \mathrm{kg}^{-1}$.

Manganese content in a soil depends exclusively on the type of rock from which the soils are derived and the processes of weathering, both geochemical and pedochemical. In this respect, the common forms of Mn oxides are birnessite, lithiophorite, and hollandite (McKenzie, 1977). Awadalla (1993) found that the greatest amount of $\mathrm{Mn}$ in El-Fayoum soils was associated with the fluviolacustrine sediments, while the lowest one was found in the desert soils. Ibrahim

Fayoum J. Agric. Res. \& Dev., Vol.24, No.2, July, 2010 
(2001) found that $\mathrm{Mn}$ was predominantly occurs as organically bound forms at $\mathrm{pH}$ $<6.5$ or as $\mathrm{MnO}_{2}$ and amorphous associated forms at $\mathrm{pH}>6.5$. The first form is dominated in the soils of El-Fayoum Governorate. Sadik $\boldsymbol{e t}$ al. (2002) mentioned that the available Mn extracted with DTPA ranged 2.38-22.28 in the calcareous soils and 6.2-19.2 $\mathrm{mg} \mathrm{kg}^{-1}$ in the Nile alluvial ones.

Zinc is held in sedimentary rocks partly as adsorbed $\mathrm{Zn}^{2+}$ on fine-grained material and partly in the structure of clay minerals in which $\mathrm{Zn}$ probably substitutes for $\mathrm{Mg}^{2+}$. In the ferromagnesian minerals of soil, $\mathrm{Zn}$ occurs principally in biotite, augite and hornblend (White, 1957). Awadalla (1993) found that the greater $\mathrm{Zn}$ value in the soils of El-Fayoum Governorate was associated with the Nile alluvial soils, while the lowest one was found in the desert soils. In general, the available $\mathrm{Zn}$ constitutes a small pool of the total content, and it is in the range of $0.32-2.62 \mathrm{mg} / \mathrm{kg}$. Ibrahim (2001) found that the total $\mathrm{Zn}$ ranged $18.3-146.9 \mathrm{mg}$ $\mathrm{kg}^{-1}$, the greatest and lowest values were obtained from the Nile alluvium and aeolian sediment, respectively. The available $\mathrm{Zn}$ ranged $0.2-4.2 \mathrm{mg} \mathrm{kg}^{-1}$, and its content was more attributed to the forms of $\mathrm{Zn}$-exchangeable and organic matter fractions. Sadik et al. (2002) revealed that the available $\mathrm{Zn}$ extracted with DTPA ranged $0.32-10.52 \mathrm{mg} \mathrm{kg}^{-1}$ in the calcareous soils, while its values ranged 0.20 $3.20 \mathrm{mg} \mathrm{kg}^{-1}$ in the Nile alluvial ones.

Copper recorded the greatest and lowest values in the Nile alluvial and sandy soils, respectively. The calcareous soils showed intermediate values of total $\mathrm{Cu}$ due to their low content of organic matter and clay minerals (Kishk et al., 1973). Awadalla (1993) found that the greatest amount of $\mathrm{Cu}$ in the soils of ElFayoum Governorate was associated with clayey soil derived from the Nile alluvial and fluvio-lacustrine sediments, while the lowest one was found in the desert sand soils. In this connection, $\mathrm{Cu}$ was more related to clay fraction and amorphous iron oxides, especially in the Nile alluvium and fluvio-lacustrine sediments (Ibrahim, 2001). On the other hand, the available $\mathrm{Cu}$ constitutes a small pool of the total content in these soils. The obtained data outlined by Sadik et al. (2002) showed that the available $\mathrm{Cu}$ extracted with DTPA ranged 0.30-2.82 and $0.90-6.70 \mathrm{mg} \mathrm{kg}^{-1}$ in the calcareous and the Nile alluvial soils, respectively.

One of the most important parameters for a successful and sustainable agricultural utilization is identifying the relationship between the availability of adequate nutrients for plants and soil characteristics. Such relationship is considered as a guide for the planning towards the suitable fertilization policy of different cultivated crops as well as it is drastically affected by the suitability of any soil to specific crops, in addition to determine plant needs of the essential nutrients in soils. To achieve such plan, updated database about the nutrients status in soil as related to the nutrient requirements of different crops must be conducted before recognizing accurately or best fertilizer recommendations (EISayed, 2009).

The highly productive land of El Fayoum depression is denaturing by flurried urbanization encroachment as well as desertification due to their limited fertility, which has a limited cultivated area such as in the other ones in Egypt. This phenomenon in such an enclosed depression with internal drainage condition is reflecting a serious problem for human mode that acting on a unique valued land. Egyptian National Specialized Committee (2003) expected that Egypt will lose all its old land by the year 2080 and will be mainly depend on the total newly reclaimed lands. This incredible mode must create a deep dramatic impression to the pedologists, economists and the decision makers. The problem has been clearly dawned and an urgent solution has become inevitable. It is a downcast

Fayoum J. Agric. Res. \& Dev., Vol.24, No.2, July, 2010 
feeling being this disastrous effect, is leading to the entire loss of this valued lands within the near coming decades, meanwhile the bare areas in Egypt is a very vast for creating a new formal demographic features.

So that, a special attention was focused to identify the inherited soil pedogenic aspects through geomorphic soil map obtained by using the visual analysis of Enhanced Images of Landsat Thematic Mapper 7 of the studied area (ETM7, 2005). The obtained soil criteria represent the first step for assessing a proper soil formation that could be considered as a promising item in soil potentiality for supplying power of essential plant nutrients and its sustainable agriculture on the long-term. The second attention was focused to support the local knowledge concerning the nutrients status in the grown plants as affected by soil properties under the prevailing environmental conditions throughout the different cyclic-sequences of the main soil sediments in El-Fayoum district. Such possible relationships are usually making to asses their significance as a guide to explain and correct the problems facing the current and future agricultural utilization projects, especially fertilization policy, in the area under investigation. Consequently, proposing the best land-use whether be under demand for agricultural purposes or be planned for later on use.

\section{MATERIALS AND METHODS: a. Materials:}

The current study was conducted on the soils of El-Fayoum district, which are developed on different soil origins, i.e., the Nile alluvium and desert formations of calcareous or siliceous in nature. Terrain data of the studied area, i.e., Enhanced Images of Landsat Thematic Mapper 7 of the bands 2, 3 and 4 with the spectral resolution of green, red and near infrared as well as special resolution is 28 to 30 meters (ETM7, 2005), topographic maps of a scale 1:50 000, GIS software (ILWIS 3.2 academic) and Global Positioning System (GPS) to collect land locations and elevations. The data were projected according to the Egyptian Transfer Mercator (ETM). Also, the pre-history or studies data and all relevant data (climatic data, drainage...etc) could be subjected to generate soil map of the studied area throughout satellite image processing \& interpretation, digitizing of maps into ILWIS GIS (2005) format for building geographic database for the main soil characteristics was established, which was added as soil attributes stored and coded using GIS and ILWIS format. Also, laboratory analysis, coding soil database attributes, updating maps of nutrient contents and interpretation could be carried out to obtain assessment of nutrient needs.

To achieve this target, a semi-detailed soil survey for the main soil properties (i.e., texture grade, bulk density, available water range, organic matter content, $\mathrm{CaCO}_{3}$ content, $\mathrm{pH}$, salinity and sodicity levels) and either total or available nutrient contents (i.e., $\mathrm{N}, \mathrm{P}, \mathrm{K}, \mathrm{Fe}, \mathrm{Mn}, \mathrm{Zn}$ and $\mathrm{Cu}$ ) in El-Fayoum district soils through based on a grid system with $2 \mathrm{~km}$ lag interval. The possible relationships between both total and available nutrient contents and the aforementioned studied soil properties as well as their expected effects on nutrients status in grown plants of wheat were also achieved.

In order to represent all soil-mapping units, 48 soil sites were selected by using a grid system with a lag of $2 \mathrm{~km}$ distance, however, a total number of 96 soil samples were collected to represent the root zone (about $40-70 \mathrm{~cm}$ depth). The obtained soil sample were air-dried, ground gently, sieved through $2 \mathrm{~mm}$ sieve and kept in glass bottles for determining the main soil physical and chemical properties. According to the obtained data of the main soil physico-chemical

Fayoum J. Agric. Res. \& Dev., Vol.24, No.2, July, 2010 
properties, sixteen representative soil sites were chosen to achieve the possible relationships between both total and available nutrient contents and the determined soil properties. The locations of the representative soil sites are illustrated in Map (1) and presented in Table (1).

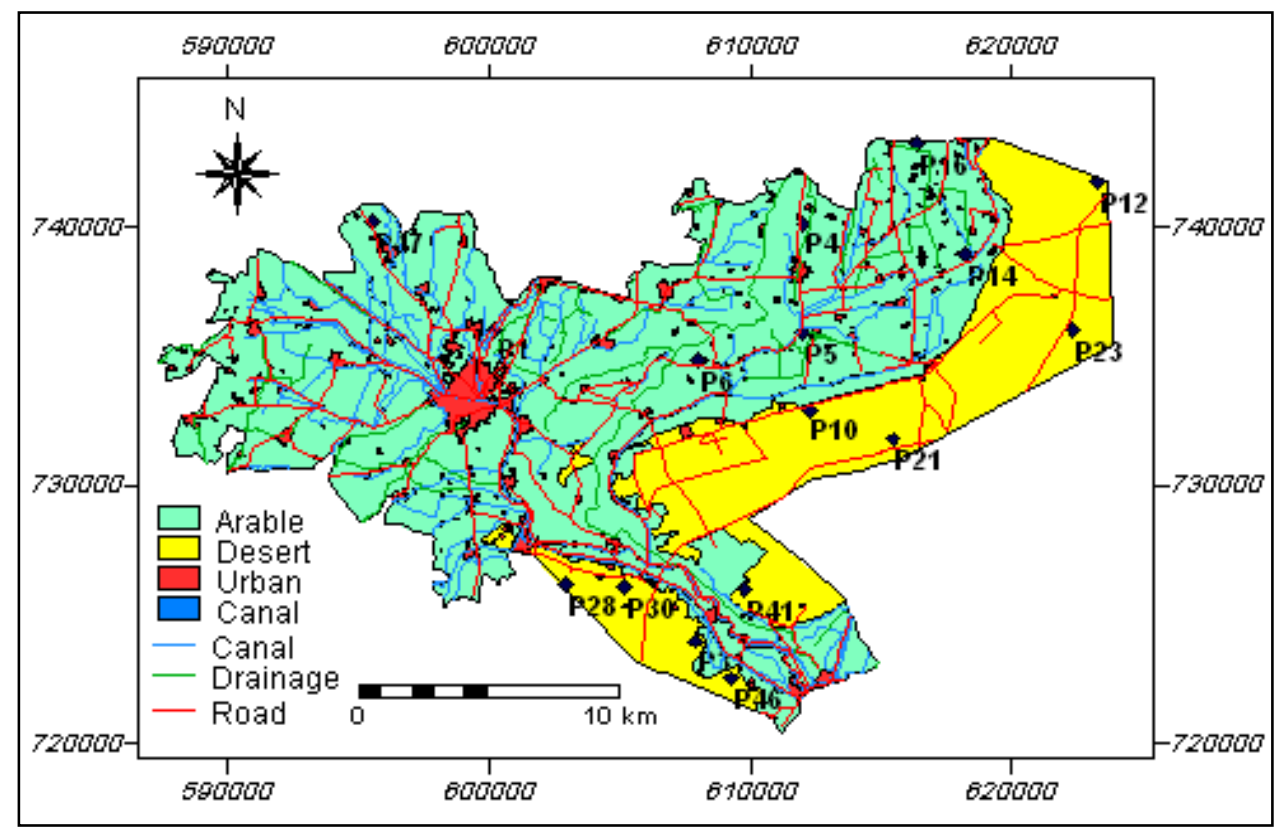

Map (1): The location of the representative soil sites.

Table (1): The locations of the representative soil sites.

\begin{tabular}{|c|c|c|c|c|}
\hline \multirow{2}{*}{$\begin{array}{l}\text { Parent } \\
\text { material }\end{array}$} & \multirow{2}{*}{$\begin{array}{l}\text { Soil site } \\
\text { No. }\end{array}$} & \multicolumn{2}{|c|}{ GPS (Geo-reference) } & \multirow{2}{*}{ Location } \\
\hline & & $\mathrm{X}$ & $\mathrm{Y}$ & \\
\hline \multicolumn{5}{|c|}{ Clayey soils } \\
\hline $\begin{array}{l}\text { The Nile } \\
\text { alluvium }\end{array}$ & 1 & 600165.17 & 736000.59 & $\begin{array}{l}\text { Mid-distance between El Fayoum City and Ezbet } \\
\text { El-Hadeir with about } 150 \mathrm{~m} \text { west of the road. }\end{array}$ \\
\hline $\begin{array}{l}\text { Fluvio- } \\
\text { lacustrine }\end{array}$ & 4 & 612008.71 & 740094.72 & About $400 \mathrm{~m}$ south-east Ezbet Mohamed Aziz \\
\hline $\begin{array}{c}\text { Eocene } \\
\text { limestone }\end{array}$ & 16 & 616402.72 & 743154.82 & About 300 m south-west Ezbet Hanna Saleh \\
\hline \multicolumn{5}{|c|}{ Sandy clay loam soils } \\
\hline $\begin{array}{l}\text { Fluvio- } \\
\text { lacustrine }\end{array}$ & 5 & 611971.81 & 735864.76 & $\begin{array}{l}\text { South Siayla village with about } 2 \mathrm{~km} \text {, and } 500 \text { west } \\
\text { Ezbet Ali Soliman }\end{array}$ \\
\hline \multirow{3}{*}{$\begin{array}{l}\text { Eocene } \\
\text { limestone }\end{array}$} & 14 & 618232.20 & 738904.34 & $\begin{array}{l}\text { West of Bahr Wahby and adjacent to Ezbet Mousa } \\
\text { Ghaleb with a distance of } 50 \mathrm{~m}\end{array}$ \\
\hline & 30 & 605164.79 & 726031.55 & $\begin{array}{l}\text { About } 800 \mathrm{~m} \text { nourth-west of Al-Azab Poultry } \\
\text { Breeding Station }\end{array}$ \\
\hline & 41 & 609798.62 & 725918.80 & $\begin{array}{l}\text { About } 150 \mathrm{~m} \text { east Ezbet Girgis and about } \\
50 \mathrm{~m} \text { east the main road }\end{array}$ \\
\hline $\begin{array}{l}\text { The Nile } \\
\text { alluvium }\end{array}$ & 47 & 595526.90 & 740151.56 & $\begin{array}{l}\text { About } 650 \mathrm{~m} \text { north-west Beni-Saleh adjacent to the } \\
\text { main road with }\end{array}$ \\
\hline \multicolumn{5}{|c|}{ Loamy sand and sandy loam soils } \\
\hline $\begin{array}{l}\text { The Nile } \\
\text { alluvium }\end{array}$ & 6 & 608014.92 & 734808.32 & $\begin{array}{l}\text { About } 700 \mathrm{~m} \text { west Manshat Demo, about } 250 \mathrm{~m} \\
\text { west of the main road }\end{array}$ \\
\hline $\begin{array}{l}\text { Fluvio- } \\
\text { lacustrine }\end{array}$ & 12 & 623310.35 & 741680.43 & $1200 \mathrm{~m}$ south-west Gabal El-Rous \\
\hline
\end{tabular}

Fayoum J. Agric. Res. \& Dev., Vol.24, No.2, July, 2010 
SIGNIFICANCE OF INHERITED SOIL PEDOGENIC ASPECTS ..... 44

Table (1): Cont.

\begin{tabular}{|c|c|c|c|c|}
\hline \multirow{2}{*}{$\begin{array}{l}\text { Parent } \\
\text { material }\end{array}$} & \multirow{2}{*}{$\begin{array}{l}\text { Soil site } \\
\text { No. }\end{array}$} & \multicolumn{2}{|c|}{ GPS (Geo-reference) } & \multirow{2}{*}{ Location } \\
\hline & & $\mathrm{X}$ & $\mathrm{Y}$ & \\
\hline \multicolumn{5}{|c|}{ Loamy sand and sandy loam soils } \\
\hline \multirow{3}{*}{$\begin{array}{l}\text { Eocene } \\
\text { limestone }\end{array}$} & 21 & 615449.51 & 731740.85 & $\begin{array}{l}\text { The inter-zone between the Nile alluvium and } \\
\text { desert formation, south-east Gabal El-Rous }\end{array}$ \\
\hline & 31 & 607886.23 & 723939.36 & $\begin{array}{l}\text { About } 850 \mathrm{~m} \text { west Hawaret Adlan and about } 350 \mathrm{~m} \\
\text { south-west Sidi Said }\end{array}$ \\
\hline & 46 & 609284.26 & 722484.20 & $\begin{array}{c}\text { About } 950 \text { m west Hawaret Adlan and about } 200 \mathrm{~m} \\
\text { south-west Sidi Khedr }\end{array}$ \\
\hline \multicolumn{5}{|r|}{ Sandy soils } \\
\hline $\begin{array}{c}\text { Desert } \\
\text { formation }\end{array}$ & 10 & 612230.91 & 732876.68 & $\begin{array}{l}\text { East Bahr Wahby and El Fayoum Company for } \\
\text { Milk Production, } 250 \mathrm{~m} \text { east Ezbet Romeeh }\end{array}$ \\
\hline \multirow{2}{*}{$\begin{array}{l}\text { Eocene } \\
\text { limestone }\end{array}$} & 23 & 622347.80 & 735964.75 & $\begin{array}{l}\text { About } 1500 \mathrm{~m} \text { south-east Rail-way of Al-Rous } \\
\text { Station }\end{array}$ \\
\hline & 28 & 602939.06 & 726150.42 & $\begin{array}{l}\text { About } 800 \mathrm{~m} \text { south-west Arabic Company for } \\
\text { Cotton }\end{array}$ \\
\hline
\end{tabular}

The positive or negative reflections of these relationships on the grown plants (wheat) at either vegetative growth or harvest stages during a growing winter season of 2009/2010 among nine soil sites were also taken into consideration in this study. Wheat seeds (Sakha $93 \mathrm{cv}$.) were sown in the chosen nine fields at the last November 2009 and harvested after 150 days. The doses of $\mathrm{N}, \mathrm{P}$ and $\mathrm{K}$ fertilizers and periods of application for wheat were carried out as the recommendations of Ministry of Agriculture, Egypt. However, the applied rate supplied from calcium superphosphate $\left(15.5 \% \mathrm{P}_{2} \mathrm{O}_{5}\right)$ was applied as a pretreatment at two weeks before sowing and incorporation of the experimental soil. Nitrogen and potassium fertilizers were added at the rates of 120 and $48 \mathrm{~kg} / \mathrm{fed}$, in equal two doses after 15 and 40 days from sowing, in forms of ammonium sulphate $(20.5 \% \mathrm{~N})$ and potassium sulphate $\left(48 \% \mathrm{~K}_{2} \mathrm{O}\right)$, respectively. The normal cultural practices for wheat crop were applied as recommended in the area under consideration.

At tillering stage, plant samples were taken to determined the vegetative growth characters, i.e., plant height, dry weight/plant, No. of tillers, leaf area/plant, chlorophyll a and b. In addition, soil samples were also taken at the identified depths from each field to be chemically analyzed for the available $\mathrm{N}, \mathrm{P}$, $\mathrm{K}, \mathrm{Fe}, \mathrm{Mn}, \mathrm{Zn}$ and $\mathrm{Cu}$. Moreover, plant samples were selected from the same fields, dried at $70{ }^{\circ} \mathrm{C}$, ground in a Willy mill and digested with acid mixture according to Parkinson and Allen (1975). The digested samples were analyzed for determining the uptake contents of $\mathrm{N}, \mathrm{P}, \mathrm{K}, \mathrm{Fe}, \mathrm{Mn}, \mathrm{Zn}$ and $\mathrm{Cu}$.

At harvest stage, some spike parameters were determined, i.e., length, weight, Nos. $/ \mathrm{m}^{2}$, No. of grain and weight of grains/spike. After that, plant samples were separated into grain and straw, and then weight of 1000 grain, grain and straw yields as well as some grain chemical constituents (i.e., protein, carbohydrate, total amino acids and total sugar contents) were determined.

\section{b. Laboratory analysis:}

The collected soil samples, disturbed and undisturbed ones, are subjected to determine particle size distribution (Gee and Bauder, 1986), using sodium hexameta phosphate as dispersing agent Richards (1954). Soil bulk density was determined using undisturbed soil sample using metal cores as described by Black et al. (1965). Available water range was calculated as the difference in moisture content $\%$ between field capacity and wilting point (Klute, 1986). $\mathrm{CaCO}_{3}$ content was determined volumetrically by using Scheibler's Calcimeter (Wright, 1939).

Fayoum J. Agric. Res. \& Dev., Vol.24, No.2, July, 2010 
Organic matter was determined using the Walkley-Black dichromate acid oxidation method according to Jackson (1967). Soil pH was measured in 1:2.5 soil water suspensions by using a $\mathrm{pH}$ meter according to U.S. Salinity Lab Staff (1969). Soil paste extract was prepared for determining electrical conductivity (ECe) or soluble ions and soil sodicity (ESP) according to Jackson (1967).

Total contents of $\mathrm{N}, \mathrm{P}, \mathrm{K}, \mathrm{Fe}, \mathrm{Mn}, \mathrm{Zn}$ and $\mathrm{Cu}$ were determined in the digested soil samples (Hesse, 1971), however, $\mathrm{N}$ was determined using Kjeldahl method (Jackson, 1973), P (Houba et al., 1995), K (Flame Spectro-Photometer), $\mathrm{Fe}, \mathrm{Mn}, \mathrm{Zn}$ and $\mathrm{Cu}$ (Atomic Absorption Spectro- Photometer, model GBC 932). Available macronutrients of $\mathrm{N}, \mathrm{P}$ and $\mathrm{K}$ in soil were extracted by $1 \%$ potassium sulphate, $0.5 \mathrm{M}$ sodium bicarbonate and $1 \mathrm{~N}$ ammonium acetate, respectively (Soltanpour and Schwab, 1977) and their contents in soil were determined according to Jackson (1973). Available micronutrients of $\mathrm{Fe}, \mathrm{Mn}, \mathrm{Zn}$, and $\mathrm{Cu}$ in soil were extracted using diethylene triamine penta acetic acid (DTPA) by a solution consisting of $0.005 \mathrm{M} \mathrm{DTPA}, 0.01 \mathrm{M} \mathrm{CaCl}_{2}$ and $0.1 \mathrm{M}$ TEA (tri-ethanolamine) with the $\mathrm{pH}$ adjusted to 7.3 by hydrochloric acid (1:1) according to Follet and Lindsay (1971) and Lindsay and Norvell (1978). The ratio of the soil to the extractant was 1: 2 and the extracting time was two hours of continuous shaking and the extract was filtered through a Whatman number 42 filter paper and determined by using Atomic Absorption Spectro-photometer (model GBC 932). The obtained results of the different soil properties were statistically analyzed by using the program outlined by SPSS (2003) software to distinguish the possible statistical relationships of simple correlations, multiple regression equations and stepwise regression between available and total nutrient contents on one hand and the different studied soil characteristics on the other one.

Chlorophyll a and $\mathrm{b}$ as $\mathrm{mg} / \mathrm{g}$ fresh weight was extracted from fresh leaves by acetone $(80 \%)$, and then their concentrations were determined according to Welburn and Lichtenthaler (1984). Total carbohydrates as $g / 100 \mathrm{~g}$ dry weight as well as in dry grains (\%) was extracted by sulphuric acid $(0.1 \mathrm{~N})$, and then determined colorimetrically by using phenol-sulphuric acid reagent according to the method described by Michel et al. (1956). Total sugars as g/100g dry weight were determined in ethanolic extract using phosphomolybdic acid reagent as described by A.O.A.C. (1995). Total free amino acids as $\mathrm{mg} / \mathrm{g}$ fresh weight were determined colorimetrically in ethanolic extract using ninhydrin reagent according to the method described by Jayarman (1981). Crude protein in dry grains (\%) was determined according to A.O.A.C (1995). The obtained data were subjected to statistical analysis according to the procedures outlined by Gomez and Gomez (1983). The obtained results of different soil properties and nutrient status were statistically analyzed by using the program outlined by SPSS (2003) software to distinguish the possible simple correlation coefficients, multiple regression equations, and stepwise between nutrient in both total and available fraction on one hand and the studied soil properties on the other hand.

\section{RESULTS AND DISCUSSION:}

A special attention was focused to discuss the possible variations in soil origin as related to the expected complicated variability in the soil constituents (i.e., inherited pedogenic characteristics) and soil potentiality for supplying power of essential plant nutrients either total or available forms as well as their positively or negatively reflections on growth and nutrients status of the grown plants, which are presented in the following items:

Fayoum J. Agric. Res. \& Dev., Vol.24, No.2, July, 2010 


\section{Soil morphology:}

In general, the representative sixteen soil sites under consideration are predominantly by deep profile (i.e., more than $150 \mathrm{~cm}$ depth below soil surface), except of some ones developed on the fluvio-lacustrine and limestone formation as their depths were limited by water table due to impermeable compacted layers (95-110 $\mathrm{cm}$ depth) and bedrock (40-65 $\mathrm{cm}$ depth), respectively. Thus, the effective soil depth could be categorized according to the proposed limits after FAO (1990) into shallow ( $<50 \mathrm{~cm}$, i.e., soil site Nos. 31 and 41$)$, moderate deep (50-100 cm, i.e., soil site Nos. 4, 14, 28, 30 and 46), deep $(100-150 \mathrm{~cm}$, i.e., soil site No. 5 ) and very deep (> $150 \mathrm{~cm}$, soil site Nos. 1, 6, 10, 12, 16, 21, 23 and 47). Consequently, the studied soil sites are characterized by a wide variation in their effective soil depth.

In contrast, there are an obvious variation in the lithological parent materials of the studied soil sites (i.e., the Nile alluvium, fluvio-lacustrine, Eocene limestone and desert formation siliceous in nature), which are more satisfactory particularly when are associated with the mineralogical composition for each of the mechanical fractions, besides the calcium carbonate component. That holds true, since these soil constituents are of the most important factors which limiting both the nutrient bearing minerals within the different soil mechanical fractions as well as availability and mobility of the essential plant nutrients status.

Morphologically, the visual features of mottling to be applicable to identify a bad soil drainage condition, which can be taken into account as a limited factor for minimizing the natural problem, as shown in soil sites Nos. 4 and 5. The relatively darkness colour of the fine textured soils, especially at the fluviolacustrine deposits, is mainly due to the clay sized material is likely to contain a mixture of discrete particles that include organic material and microbial biomass (He et al., 1995). Also, it has been generally accepted that soil structure is more affected by many soil variables, particularly soil texture that is graded into sand, loamy sand, sandy loam, sandy clay loam and clay. The corresponding soil structure is also graded into single grain structure that dominated in the relatively coarse textured soils, granular and sub-angular blocky in the medium texture soils and angular blocky in the fine clayey texture, with a bad prismatic or columnar structure types in the alkaline subsoil layers.

\section{Soil physio-chemical properties:}

Data in Table (2) and Map (2) show that the studied area is comprises by different soil texture grades, i.e., sandy, loamy sand, sandy loam, sandy clay loam and clay. These clear variations are more attributed to the variability in complex nature of the parent materials, i.e., soil origins that soils under study are developed on. In addition, these variations are expected due to the pronounced differences in soil relief, weathering intensity, agent of transportation and natural sedimentation pattern or depositional regime of deposits. It is noteworthy to mention that the representative soil sites were characterized by homogeneous in their soil texture throughout the two layers of root zone $(70 \mathrm{~cm}$ depth or less) for each site. At the same times, the soils that are derived from a similar parent material could be exhibited one soil texture grade or more, i.e., soil site Nos. 1, 6 and 47 (the Nile alluvium), 4, 5 and 12 (fluvio-lacustrine) and 14, 21 and 23 (Eocene limestone). This is mainly due to the depositional regime which is mainly controlled by the wide variations of soil relief that characterized El Fayoum depression.

Soil bulk density is generally lower in the topsoil as well as in the fine textured soil, and then it tends to increase with depth and when the soil texture becomes relatively coarse. In this connection, Lawrence (1977) pointed out that

Fayoum J. Agric. Res. \& Dev., Vol.24, No.2, July, 2010 
Abdel Nasser A.A. Abdel Hafeez, et al.

bulk density is a function of soil structure, which is more related to various physical properties particularly soil available moisture range (Table 2).

Table (2): Particle size distribution, bulk density, available water, $\mathrm{CaCO}_{3}$ content, organic matter content and ESP of the representative soil sites.

\begin{tabular}{|c|c|c|c|c|c|c|c|c|c|c|c|c|}
\hline \multirow[b]{2}{*}{ 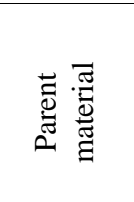 } & \multirow[b]{2}{*}{ 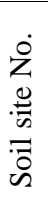 } & \multirow[b]{2}{*}{$\begin{array}{c}\text { Depth } \\
\text { (cm) }\end{array}$} & \multicolumn{4}{|c|}{ Particle size distribution $\%$} & \multirow[b]{2}{*}{$\begin{array}{c}\text { Modified } \\
\text { texture } \\
\text { class }\end{array}$} & \multirow[b]{2}{*}{ 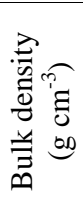 } & \multirow[b]{2}{*}{ 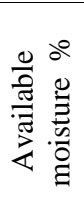 } & \multirow[b]{2}{*}{$\begin{array}{l}0^{0} \\
0^{m} \\
0 \\
0\end{array}$} & \multirow[b]{2}{*}{ 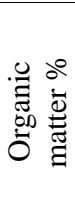 } & \multirow[b]{2}{*}{ 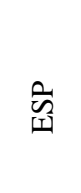 } \\
\hline & & & 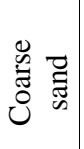 & 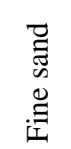 & $=$ & $\vec{\Xi}$ & & & & & & \\
\hline \multicolumn{13}{|c|}{ Clayey soils } \\
\hline \multirow{2}{*}{$\begin{array}{l}\text { The Nile } \\
\text { alluvium }\end{array}$} & \multirow{2}{*}{1} & $0-20$ & 1.5 & 13.2 & 27.9 & 57.4 & \multirow{6}{*}{$\mathrm{C}$} & 1.14 & 23.40 & 5.91 & 2.85 & 7.35 \\
\hline & & $20-70$ & 0.8 & 11.8 & 23.9 & 63.5 & & 1.18 & 21.78 & 4.55 & 2.14 & 8.74 \\
\hline \multirow{2}{*}{$\begin{array}{l}\text { Fluvio- } \\
\text { lacustrine }\end{array}$} & \multirow{2}{*}{4} & $0-15$ & 3.2 & 15.8 & 26.1 & 54.9 & & 1.19 & 18.25 & 13.97 & 2.45 & 11.85 \\
\hline & & $15-70$ & 1.7 & 17.4 & 29.3 & 51.6 & & 1.22 & 17.93 & 15.25 & 1.79 & 13.47 \\
\hline \multirow{2}{*}{$\begin{array}{c}\text { Eocene } \\
\text { limestone }\end{array}$} & \multirow{2}{*}{16} & $0-25$ & 6.4 & 18.7 & 21.8 & 53.1 & & 1.31 & 14.80 & 25.46 & 1.61 & 18.60 \\
\hline & & $25-70$ & 5.8 & 17.5 & 20.0 & 56.7 & & 1.35 & 13.54 & 24.70 & 0.82 & 21.53 \\
\hline \multicolumn{13}{|c|}{ Sandy clay loam soils } \\
\hline \multirow{2}{*}{$\begin{array}{c}\text { Fluvio- } \\
\text { lacustrine }\end{array}$} & \multirow{2}{*}{5} & $0-15$ & 9.1 & 38.6 & 19.5 & 32.8 & \multirow{10}{*}{ SCL } & 1.35 & 17.82 & 11.92 & 2.29 & 11.90 \\
\hline & & $15-70$ & 13.2 & 34.9 & 16.5 & 35.4 & & 1.41 & 16.85 & 13.54 & 2.15 & 13.75 \\
\hline \multirow{6}{*}{$\begin{array}{c}\text { Eocene } \\
\text { limestone }\end{array}$} & \multirow{2}{*}{14} & $0-20$ & 15.4 & 33.1 & 24.0 & 27.5 & & 1.39 & 13.97 & 30.20 & 0.49 & 14.60 \\
\hline & & $20-65$ & 17.7 & 34.5 & 26.2 & 22.6 & & 1.48 & 12.63 & 29.09 & 0.27 & 15.85 \\
\hline & & $0-10$ & 9.8 & 41.5 & 27.4 & 21.3 & & 1.44 & 11.50 & 41.45 & 0.31 & 17.40 \\
\hline & 30 & $10-55$ & 15.5 & 31.8 & 28.0 & 24.7 & & 1.50 & 10.65 & 40.83 & 0.19 & 19.75 \\
\hline & & $0-15$ & 8.0 & 49.7 & 15.2 & 27.1 & & 1.49 & 10.72 & 47.19 & 0.20 & 27.83 \\
\hline & 41 & $15-45$ & 10.7 & 35.0 & 21.9 & 32.4 & & 1.57 & 9.45 & 52.50 & 0.15 & 32.91 \\
\hline The Nile & & $0-30$ & 14.4 & 32.1 & 18.1 & 35.4 & & 1.29 & 22.94 & 3.25 & 1.72 & 3.56 \\
\hline alluvium & 47 & $30-70$ & 9.9 & 34.0 & 26.8 & 29.3 & & 1.32 & 20.50 & 2.74 & 0.95 & 4.25 \\
\hline & & & & Loan & sand & nd san & & & & & & \\
\hline The Nile & & $0-25$ & 32.9 & 40.1 & 12.7 & 14.3 & & 1.41 & 15.20 & 3.97 & 1.15 & 2.75 \\
\hline alluvium & 6 & $25-70$ & 37.2 & 30.9 & 14.4 & 17.5 & & 1.47 & 14.95 & 3.04 & 0.86 & 4.12 \\
\hline Fluvio- & & $0-30$ & 19.5 & 46.4 & 18.5 & 15.6 & SL & 145 & 16.41 & 15.60 & 1.35 & 5.07 \\
\hline lacustrine & 12 & $30-70$ & 26.4 & 38.8 & 15.6 & 19.2 & & 1.49 & 17.35 & 13.95 & 1.12 & 6.10 \\
\hline & & $0-25$ & 43.0 & 38.3 & 7.8 & 10.9 & & 150 & 9.89 & 24.80 & 0.24 & 10.94 \\
\hline & 21 & $25-70$ & 39.1 & 44.5 & 6.9 & 9.5 & & 1.53 & 8.70 & 27.15 & 0.13 & 13.17 \\
\hline Eocene & & $0-10$ & 15.7 & 65.0 & 8.4 & 10.9 & & 1.52 & 8.85 & 34.22 & 0.17 & 15.85 \\
\hline limestone & 31 & $10-40$ & 19.0 & 62.3 & 7.5 & 11.2 & LS & 1.55 & 9.10 & 35.45 & 0.09 & 19.20 \\
\hline & & $0-15$ & 24.8 & 56.2 & 9.2 & 9.8 & & 1.56 & 7.67 & 45.12 & 0.11 & 29.05 \\
\hline & 46 & $15-50$ & 21.5 & 60.0 & 7.5 & 11.0 & & 1.57 & 7.15 & 41.98 & 0.07 & 32.10 \\
\hline & & & & & & dy soi & & & & & & \\
\hline Desert & & $0-20$ & 72.6 & 15.9 & 8.7 & 2.8 & & 1.63 & 5.75 & 0.97 & 0.11 & 5.90 \\
\hline formation & 10 & $20-70$ & 68.9 & 18.0 & 10.2 & 2.9 & & 1.69 & 6.10 & 1.40 & 0.06 & 7.15 \\
\hline & 23 & $0-25$ & 51.1 & 36.4 & 9.4 & 3.1 & & 1.57 & 4.95 & 19.57 & 0.14 & 16.45 \\
\hline Eocene & 23 & $25-70$ & 45.4 & 43.1 & 7.6 & 3.9 & S & 1.61 & 4.62 & 18.64 & 0.09 & 21.06 \\
\hline limestone & & $0-30$ & 38.5 & 48.2 & 8.8 & 4.5 & & 1.52 & 5.16 & 53.92 & 0.25 & 26.50 \\
\hline & 28 & $30-55$ & 31.3 & 56.6 & 6.9 & 5.2 & & 1.58 & 4.98 & 60.55 & 0.14 & 29.36 \\
\hline
\end{tabular}

Fine earth: $\mathrm{S}=\mathrm{Sand}, \mathrm{LS}=$ Loamy sand, $\mathrm{SL}=$ Sandy loam, $\mathrm{SCL}=$ Sandy clay loam, $\mathrm{C}=$ Clay.

The later soil character shows a parallel reduction, in most cases, contemporary associated with augmenting the bulk density values, being more related to the dominant of coarse textured soils. That is also true, since Na-salinity or sodicity (ESP) negatively affects both soil bulk density and available moisture values due to soil aggregation tends to be less stable (Batey, 1990). It is noteworthy to mention that the relatively coarse textured soils are characterized by a balanced soil skeletal media of relatively high bulk density and low available

Fayoum J. Agric. Res. \& Dev., Vol.24, No.2, July, 2010 
moisture, mainly due to their solid constituents are more resistant to be reoriented. The reverse is true for medium and fine textured soils due to matrix and capillary potentials enhance the ability of soil to retain relatively high moisture content.

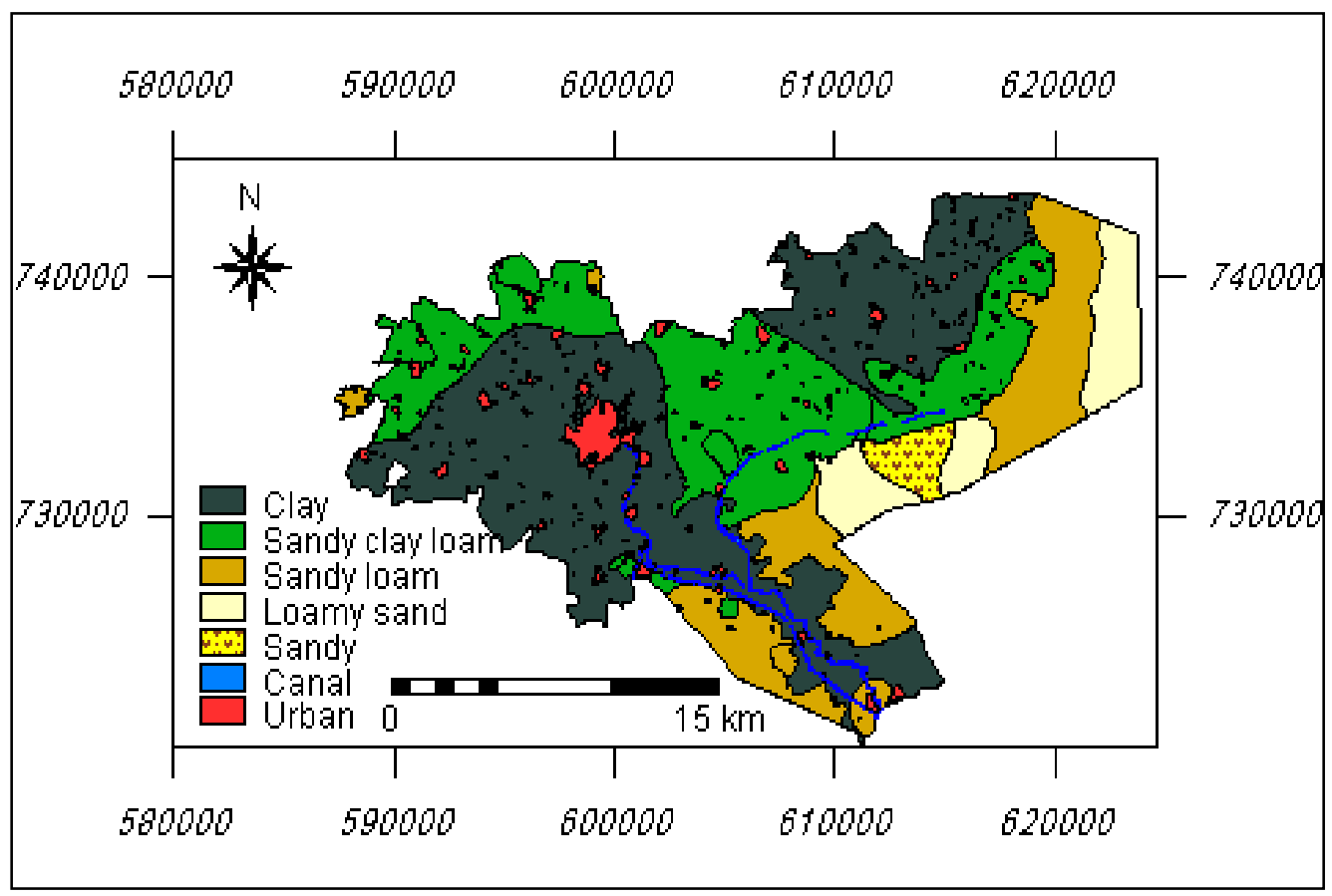

Map (2): Categories of soil texture grades among the studied area.

As shown in Table (2) and Map (3), $\mathrm{CaCO}_{3}$ contents in the studied soils developed on the Eocene limestone as a parent material are mostly act as an active form, except of those developed on the physically weathered ones under the prevailing arid condition of sand soil in texture. It could be suggested that there is a relationship between soil $\mathrm{CaCO}_{3}$ content and soil parent material, which showed a relatively low content $(<6 \%)$ in both the desert formation siliceous in nature (soil site No. 10) and the Nile alluvium (soil site Nos. 1, 6 and 47), moderate content $(<16 \%)$ in the soils developed on the fluvio-lacustrine deposits (soil site Nos. 4, 5 and 12) and high content (>18\%) in soil developed on the Eocene limestone as a parent material.

Soil organic matter content shows a comparatively wide range of 0.06 (soil site No. 10 of sandy soil siliceous in nature) $2.85 \%$ (soil site No. 1 of the clayey Nile alluvial soil), as shown in Table (2). It is well known that the relatively high content of soil organic matter is associated with the continuous cultivation and soil agro-management practices, especially soil manuring. It is noteworthy to mention that organic materials in the soil are more positively affected the micronutrients availability, particularly those are largely present as insoluble forms. Also, the decomposition of soil organic matter can be increased through the effect of soil redox potential (Lindsay, 1991). The active organic acids (net products of soil organic matter) such as fulvic acid will also help to increase micronutrients solubility and their availability to uptake by plants. In addition, soil organic matte is one of the main sources and sinks of nutrients, and should theoretically show a strong relationship with the nutrients status of the soil.

Fayoum J. Agric. Res. \& Dev., Vol.24, No.2, July, 2010 


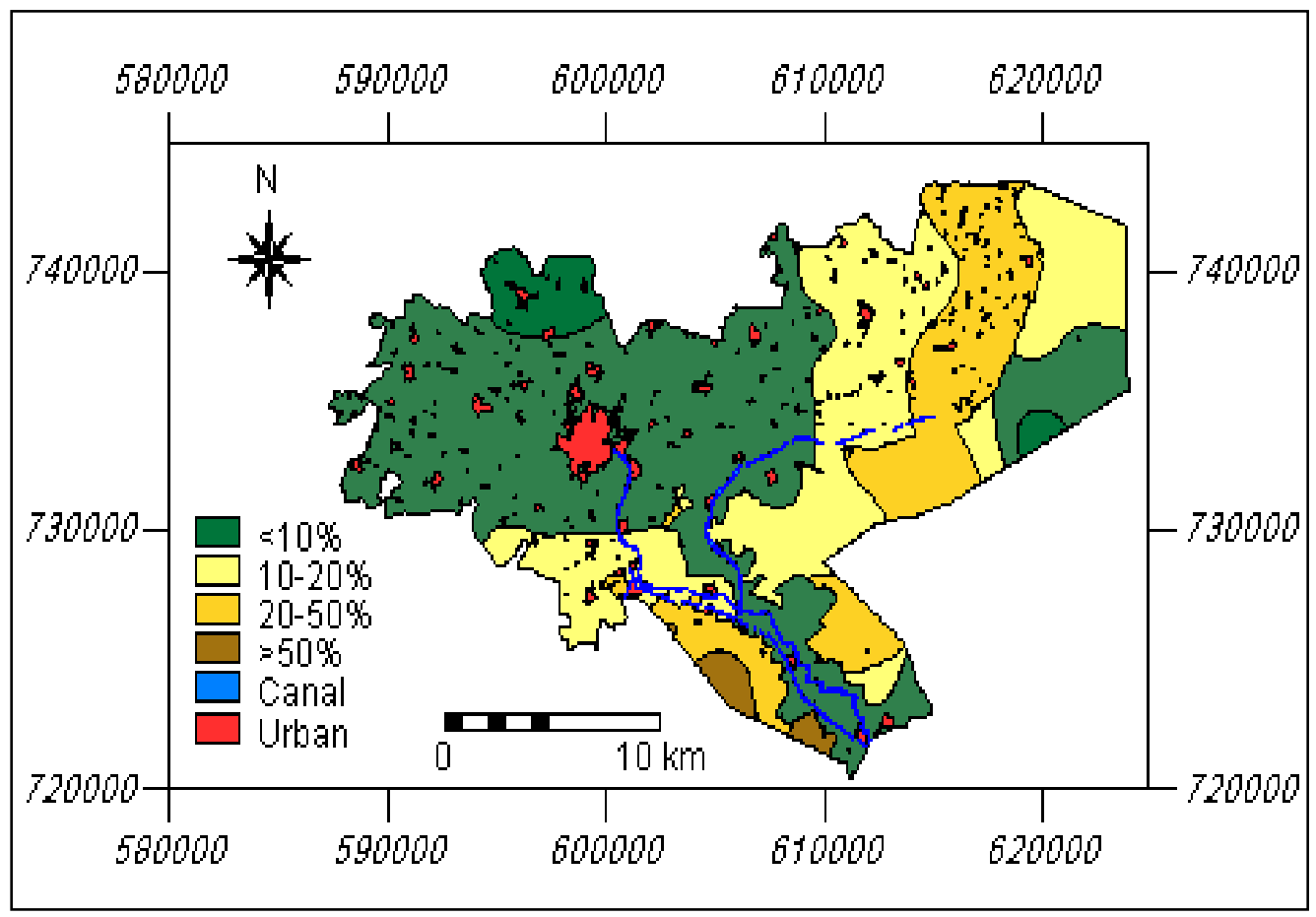

\section{Map (3): Categories of soil $\mathrm{CaCO}_{3}$ grades among the studied area.}

Data presented in Table (3) and map (4) reveal that the studied soil sites are characterized by different salinity levels, where ECe values ranged between 0.87$3.25 \mathrm{dSm}^{-1}$ (non-saline) and $165.92 \mathrm{dSm}^{-1}$ (extremely highly saline). The relatively low salinity soils are developed on the Nile alluvium (soil site Nos. 1, 6 and 47) and desert formation siliceous in nature (soil site No. 10). Whereas, the highly saline soils are developed on the caronitic weathered ones (soil site No. 41), indicate that these accumulated salts are mainly inherited from the chemical weathering of Eocene limestone under the aqueos medium of ancient lake "Lake Moris". Also, it should be mentioned here that some soils are characterized by slight or moderate salinity levels $\left(4-12 \mathrm{dSm}^{-1}\right)$, i.e., those are developed on both fluvio-lacustrine (soil site Nos. 4, 5 and 12) and Eocene limestone (soil site Nos. 16 and 21). In general, sodium is the predominant soluble cation, followed by $\mathrm{Ca}^{2+}$, sometimes $\mathrm{Mg}^{2+}$ and $\mathrm{K}^{+}$vs $\mathrm{Cl}$, sometimes $\mathrm{SO}_{4}{ }^{2-}$ and $\mathrm{HCO}_{3}{ }^{-}$as the dominant anions, indicate that $\mathrm{NaCl}$ is the predominant soluble salt. $\mathrm{Mg}^{2+}$ ions are dominating $\mathrm{Ca}^{2+}$ ones, especially in soils developed on the fluvio-lacustrine deposits or some of Eocene limestone, such phenomenon is more attributed to submerging with $\mathrm{Mg}$-enriched lake water or Mg-bearing minerals, respectively.

Soil $\mathrm{pH}$ is considered as one of the most important factors affecting the availability, mobility and uptake of essential nutrients for plants, particularly of micronutrients (Kabata Pendias, 2001). Data presented in Table (3) show that the studied soils having different $\mathrm{pH}$ values ranged between 7.45 (soils developed on the Nile alluvium) and 8.82 (soils developed on the Eocene limestone). Such wide variations are more attributed to the nature of soil mineral and organic constituents as a solid phase as well as $\mathrm{CaCO}_{3}$ content and biological activity of microorganisms, particularly those generate longer or shorter immobilization $\mathrm{NH}_{4}$

Fayoum J. Agric. Res. \& Dev., Vol.24, No.2, July, 2010 
as well as nitrification of the released $\mathrm{NH}_{4}{ }^{+}$. These include permanent $(\mathrm{pH}-$ independent) base-exchange sorption by soil complex and non-exchange fixation in the space between sheets of clay minerals (Wei et al., 2006).

Table (3): Chemical analysis of soil paste extract of the representative soil sites.

\begin{tabular}{|c|c|c|c|c|c|c|c|c|c|c|c|c|}
\hline \multirow{2}{*}{$\begin{array}{c}\text { Parent } \\
\text { material }\end{array}$} & \multirow{2}{*}{$\begin{array}{c}\text { Soil site } \\
\text { No. }\end{array}$} & \multirow{2}{*}{$\begin{array}{l}\text { Depth } \\
(\mathrm{cm})\end{array}$} & \multirow{2}{*}{$\begin{array}{l}\text { Soil } \\
\mathrm{pH}^{*}\end{array}$} & \multirow{2}{*}{$\begin{array}{c}\mathrm{ECe} \\
(\mathrm{dS} / \mathrm{m})\end{array}$} & \multicolumn{4}{|c|}{ Soluble cations $\left(\mathrm{m} \mathrm{mmolc}^{-1}\right)$} & \multicolumn{4}{|c|}{ Soluble anions (m mmolc $\mathrm{L}^{-1}$ ) } \\
\hline & & & & & $\mathrm{Ca}^{2+}$ & $\mathrm{Mg}^{2+}$ & $\mathrm{Na}^{+}$ & $\mathrm{K}^{+}$ & $\mathrm{CO}_{3}{ }^{2-}$ & $\mathrm{HCO}_{3}^{-}$ & $\mathrm{Cl}^{-}$ & $\mathrm{SO}_{4}{ }^{2-}$ \\
\hline \multicolumn{13}{|c|}{ Clayey soils } \\
\hline \multirow{2}{*}{$\begin{array}{l}\text { The Nile } \\
\text { alluvium }\end{array}$} & \multirow[b]{2}{*}{1} & $0-20$ & 7.84 & 2.41 & 9.25 & 4.20 & 10.35 & 0.60 & 0.00 & 2.45 & 11.50 & 10.75 \\
\hline & & $0-70$ & 90 & & 11.76 & 5.84 & & & & & 15.10 & \\
\hline \multirow{2}{*}{$\begin{array}{c}\begin{array}{c}\text { Fluvio- } \\
\text { lacustrine }\end{array} \\
\end{array}$} & & $0-15$ & .95 & & 1.35 & 15.70 & & & & & & \\
\hline & & $15-70$ & .05 & 32 & & 17.24 & & & & & & \\
\hline \multirow{2}{*}{$\begin{array}{c}\text { Eocene } \\
\text { limestone }\end{array}$} & \multirow{2}{*}{16} & & & & & & & & & & & \\
\hline & & $25-$ & & & & & & & & & & \\
\hline \multicolumn{13}{|c|}{ Sandy clay loam soils } \\
\hline \multirow{2}{*}{\begin{tabular}{|c|}
$\begin{array}{c}\text { Fluvio- } \\
\text { lacustrine }\end{array}$ \\
\end{tabular}} & & & & & & & & & & & & \\
\hline & & $15-$ & & & & & & & & & & \\
\hline \multirow{6}{*}{$\begin{array}{l}\text { Eocene } \\
\text { limestone }\end{array}$} & & & & & & & & & & & & \\
\hline & & 20 & & & & & & & & & & \\
\hline & \multirow{2}{*}{30} & & & & & & & & & & & \\
\hline & & & & & & & & & & & & \\
\hline & & & & & & & & & & & & \\
\hline & & $15-45$ & & 137.04 & 35.80 & 64 & & & & & 5.7 & 3.90 \\
\hline \multirow{2}{*}{$\begin{array}{l}\text { The Nile } \\
\text { alluvium }\end{array}$} & \multirow{2}{*}{47} & & & & & & & & & & & \\
\hline & & & & 2.45 & 10.12 & 3.23 & 11.05 & 0.4 & & & & \\
\hline \multicolumn{13}{|c|}{ Loamy sand and sandy loam soils } \\
\hline & & & & & & & & & & 1. & .85 & 3.25 \\
\hline & 6 & & & & & & & & & & & \\
\hline Fluvio- & & & & & & & & & & & 00 & 90 \\
\hline & & $30-70$ & & & & & & & & & & \\
\hline & & $0-25$ & 7.9 & & & 19.70 & & & & & & 40.65 \\
\hline & & $25-70$ & & & & & & & & & 75.40 & 41.50 \\
\hline Eocene & & $0-10$ & & 39.07 & & & & & & & 285.60 & 149.50 \\
\hline & & $10-40$ & & & & & & & & & & 174.75 \\
\hline & & & & & & & & & & & & \\
\hline & & & & & & 139.40 & & & & & 390.00 & \\
\hline & & & & & & & & & & & & \\
\hline Desert & & & & & & & & & & & 17. & 13.20 \\
\hline & & $20-70$ & & & & & & & & & & 9.75 \\
\hline & & & & & & 30.05 & & & & 2. & 124.75 & 90.35 \\
\hline & & $25-70$ & & & & & & & & 2.9 & 257.30 & 98.20 \\
\hline & 28 & & & & & & & & & 3.10 & 176.20 & 103.15 \\
\hline & & $30-55$ & 8.74 & 86.05 & 197.25 & 155.75 & 531.5 .0 & 3.40 & 0.00 & 3.50 & 569.00 & 315.40 \\
\hline
\end{tabular}

$*$ Soil pH was determined in 1:2.5 soil water suspensions

\section{Soil nutrients status:}

\section{a. Total nutrient contents:}

The greatly wide differences in soil characteristics as related to their various origins represent a typical model to asses the relation between the nature of soil sediments and plant essential nutrients status under the prevailing environmental conditions, in either total or available contents. 


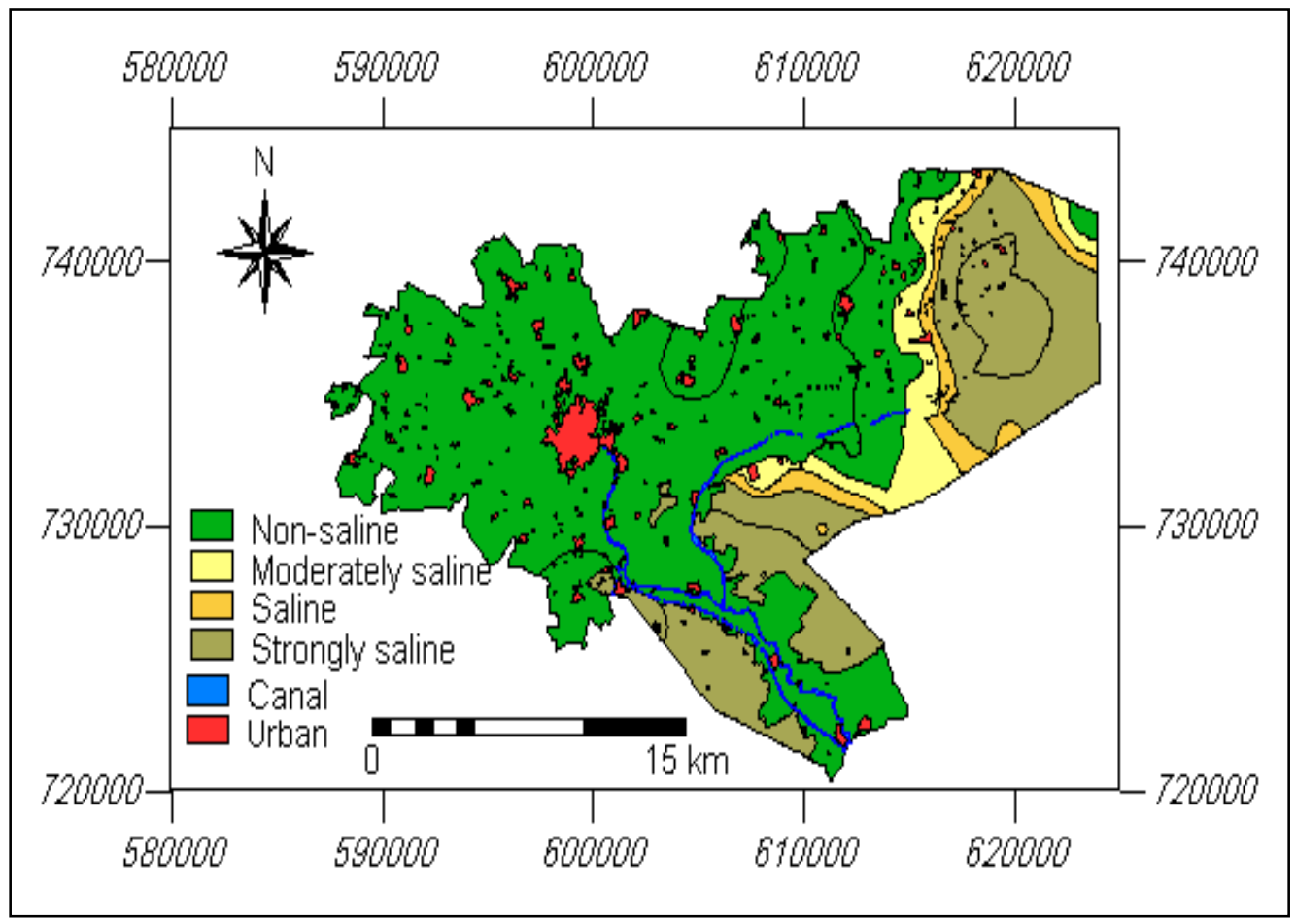

\section{Map (4): Categories of soil salinity levels among the studied area.}

Data in Tables ( 2 and 4 ) show that soil texture as a soil permanent character is greatly affects the total nutrient contents through the distribution pattern of nutrient-bearing minerals in soil mechanical fractions. In general, the nutrientsbearing mineral assemblages achieved a wide variation throughout the soil mechanical fractions, however, there are a more evidence for dominated minerals in each soil mechanical fraction and their supplying power for the released nutrients (Ibrahim, 2001). Accordingly, the soils that developed on the Nile alluvial deposits are considered of higher potentiality to release total nutrient contents on par with those are developed on the fluvio-lacustrine ones, followed by desertic formations either calcareous (Eocene limestone) or siliceous (aeolian deposits) in nature, respectively.

\section{b. Available nutrient contents:}

The obtained data of either macronutrient of N, P and K or the DTPA chemically extractable of micronutrients $\mathrm{Fe}, \mathrm{Mn}, \mathrm{Zn}$ and $\mathrm{Cu}$, Table (5), are confirmed the aforementioned trend of the total nutrient contents in the studied soils that are developed on the different soil deposits under consideration. Nevertheless, the unsuitable soil conditions of air-moisture regime, salinity, sodicity, high $\mathrm{pH}$, high $\mathrm{CaCO}_{3}$ content, low organic matter content, relatively coarse texture of low nutrient-bearing minerals, narrow available water range and inhibitive act of biological activity. Such adverseable conditions could have pronounced negatively effects on nutrients releasing, availability, mobility and uptake by plant roots. In addition, releasing the plant essential nutrients from the nutrient-bearing minerals are more affected by the intensity of chemical

Fayoum J. Agric. Res. \& Dev., Vol.24, No.2, July, 2010 
SIGNIFICANCE OF INHERITED SOIL PEDOGENIC ASPECTS ..... 52

weathering, which is more attributed to the nature of soil origin, intensive of agricultural cropping sequence and agro-management practices.

Table (4): Total nutrient contents of the representative soil sites.

\begin{tabular}{|c|c|c|c|c|c|c|c|c|c|}
\hline \multirow{2}{*}{$\begin{array}{l}\text { Parent } \\
\text { material }\end{array}$} & \multirow{2}{*}{$\begin{array}{l}\text { Soil } \\
\text { site } \\
\text { No. }\end{array}$} & \multirow{2}{*}{$\begin{array}{l}\text { Depth } \\
(\mathrm{cm})\end{array}$} & \multicolumn{3}{|c|}{ Macronutrients $\left(\mathrm{mg} \mathrm{kg}^{-1}\right)$} & \multicolumn{4}{|c|}{ Micronutrients $\left(\mathrm{mg} \mathrm{kg}^{-1}\right)$} \\
\hline & & & $\mathrm{N}$ & $\mathrm{P}$ & K & $\mathrm{Fe}$ & $\mathrm{Mn}$ & $\mathrm{Zn}$ & $\mathrm{Cu}$ \\
\hline \multicolumn{10}{|c|}{ Clayey soils } \\
\hline \multirow{2}{*}{$\begin{array}{l}\text { The Nile } \\
\text { alluvium }\end{array}$} & \multirow{2}{*}{1} & $0-20$ & 1607.5 & 791.6 & 18085.4 & 54812.1 & 396.7 & 143.0 & 87.2 \\
\hline & & $20-70$ & 1425.9 & 704.7 & 14319.0 & 49720.5 & 299.8 & 94.6 & 80.4 \\
\hline \multirow{2}{*}{$\begin{array}{c}\text { Fluvio- } \\
\text { lacustrine }\end{array}$} & \multirow[b]{2}{*}{4} & $0-15$ & 1486.4 & 780.0 & 17122.3 & 56021.8 & 378.4 & 131.9 & 79.8 \\
\hline & & $15-70$ & 1374.7 & 696.8 & 16155.4 & 52719.0 & 315.2 & 120.0 & 74.6 \\
\hline \multirow{2}{*}{$\begin{array}{c}\text { Eocene } \\
\text { limestone }\end{array}$} & \multirow{2}{*}{16} & $0-25$ & 1205.8 & 715.0 & 14525.0 & 51986.7 & 349.5 & 107.3 & 68.9 \\
\hline & & $25-70$ & 1003.0 & 678.1 & 13737.9 & 52002.4 & 305.6 & 95.8 & 59.2 \\
\hline \multicolumn{10}{|c|}{ Sandy clay loam soils } \\
\hline \multirow{2}{*}{$\begin{array}{c}\text { Fluvio- } \\
\text { lacustrine }\end{array}$} & \multirow{2}{*}{5} & $0-15$ & 1439.1 & 661.7 & 10112.5 & 36143.9 & 215.0 & 74.7 & 55.4 \\
\hline & & $15-70$ & 1399.8 & 701.0 & 9678.2 & 35748.5 & 199.8 & 69.2 & 50.7 \\
\hline \multirow{6}{*}{$\begin{array}{c}\text { Eocene } \\
\text { limestone }\end{array}$} & \multirow{2}{*}{14} & $0-20$ & 154.7 & 435.8 & 7145.8 & 28980.4 & 184.3 & 61.5 & 48.6 \\
\hline & & $20-65$ & 139.0 & 397.5 & 5914.2 & 26091.0 & 168.7 & 56.8 & 42.9 \\
\hline & \multirow{2}{*}{30} & $0-10$ & 117.3 & 365.9 & 6275.6 & 21918.5 & 131.3 & 49.4 & 39.5 \\
\hline & & $10-55$ & 96.5 & 284.1 & 5780.7 & 19765.8 & 124.9 & 43.7 & 34.0 \\
\hline & \multirow{2}{*}{41} & $0-15$ & 107.9 & 297.5 & 5965.1 & 2302.2 & 140.5 & 51.9 & 45.1 \\
\hline & & $15-45$ & 93.4 & 238.7 & 5597.0 & 2085.3 & 121.4 & 42.5 & 37.9 \\
\hline \multirow{2}{*}{$\begin{array}{l}\text { The Nile } \\
\text { alluvium }\end{array}$} & \multirow{2}{*}{47} & $0-30$ & 1017.5 & 597.8 & 9894.6 & 37137.0 & 271.0 & 62.9 & 59.7 \\
\hline & & $30-70$ & 873.2 & 489.5 & 8901.9 & 33085.4 & 195.2 & 57.8 & 51.3 \\
\hline \multicolumn{10}{|c|}{ Loamy sand and sandy loam soils } \\
\hline \multirow{2}{*}{$\begin{array}{l}\text { The Nile } \\
\text { alluvium }\end{array}$} & \multirow{2}{*}{6} & $0-25$ & 857.0 & 382.6 & 8003.5 & 19281.0 & 151.8 & 47.7 & 37.9 \\
\hline & & $25-70$ & 745.2 & 305.0 & 7495.9 & 17857.2 & 130.0 & 41.4 & 31.8 \\
\hline \multirow{2}{*}{$\begin{array}{c}\text { Fluvio- } \\
\text { lacustrine }\end{array}$} & & $0-30$ & 903.8 & 419.4 & 8217.6 & 20543.7 & 129.5 & 50.8 & 40.7 \\
\hline & 12 & $30-70$ & 819.7 & 365.1 & 7906.5 & 18969.8 & 115.4 & 49.1 & 35.4 \\
\hline & & $0-25$ & 113.5 & 171.9 & 6014.3 & 10201.4 & 95.7 & 39.5 & 34.3 \\
\hline & 21 & $25-70$ & 94.3 & 162.5 & 5362.1 & 11054.5 & 89.0 & 30.2 & 29.8 \\
\hline Eocene & & $0-10$ & 96.9 & 159.7 & 5404.7 & 9017.9 & 78.4 & 31.6 & 30.9 \\
\hline limestone & 31 & $10-40$ & 85.7 & 148.4 & 4986.2 & 8623.6 & 67.9 & 28.3 & 24.5 \\
\hline & & $0-15$ & 90.4 & 152.6 & 5007.5 & 8409.3 & 70.0 & 27.4 & 25.2 \\
\hline & 46 & $15-50$ & 78.5 & 141.8 & 4398.0 & 8078.7 & 62.9 & 23.2 & 20.1 \\
\hline & & & & & dy soils & & & & \\
\hline Desert & 10 & $0-20$ & 57.8 & 113.5 & 3612.9 & 6119.0 & 50.7 & 21.5 & 16.7 \\
\hline formation & 10 & $20-70$ & 48.5 & 107.2 & 3037.1 & 5726.4 & 46.5 & 18.0 & 13.8 \\
\hline & & $0-25$ & 50.7 & 101.8 & 3705.7 & 5615.5 & 47.2 & 17.8 & 14.1 \\
\hline Eocene & 23 & $25-70$ & 45.4 & 97.9 & 3140.6 & 6170.3 & 42.6 & 14.4 & 12.9 \\
\hline limestone & 28 & $0-30$ & 61.9 & 120.0 & 4115.8 & 7104.7 & 60.0 & 19.7 & 17.6 \\
\hline & 28 & $30-55$ & 55.1 & 109.7 & 3970.0 & 6690.9 & 54.3 & 16.5 & 15.4 \\
\hline
\end{tabular}

\section{Nutrients status as related to soil constituents:}

Actually, plant essential nutrients are found in the soil as soil solution free form or bounded with soil constituents in different forms. The later ones are categorized into two main forms, i.e., exchangeable and bounded with either organic (i.e., organic matter) or inorganic soil components (i.e., each of carbonate, manganese oxide, soil mechanical fraction, amorphous and crystalline iron oxides). Undoubtedly, although organic matter constituent represents a very low soil component in the studied area (0.06-2.85 \%), it plays an important role in the soil fertility status. This is mainly due to it is not only positively affects the soil physio-chemical properties through the active charged organic acids but also it is considered a source for plant nutrients. 
Table (5): Available nutrient contents of the representative soil sites.

\begin{tabular}{|c|c|c|c|c|c|c|c|c|c|}
\hline \multirow{2}{*}{$\begin{array}{c}\text { Parent } \\
\text { material }\end{array}$} & \multirow{2}{*}{$\begin{array}{l}\text { Soil } \\
\text { site } \\
\text { No. }\end{array}$} & \multirow{2}{*}{$\begin{array}{c}\text { Depth } \\
(\mathrm{cm})\end{array}$} & \multicolumn{3}{|c|}{ Macronutrients $\left(\mathrm{mg} \mathrm{kg}^{-1}\right)$} & \multicolumn{4}{|c|}{ Micronutrients $\left(\mathrm{mg} \mathrm{kg}^{-1}\right)$} \\
\hline & & & $\mathrm{N}$ & $\mathrm{P}$ & $\mathrm{K}$ & $\mathrm{Fe}$ & $\mathrm{Mn}$ & $\mathrm{Zn}$ & $\mathrm{Cu}$ \\
\hline \multicolumn{10}{|c|}{ Clayey soils } \\
\hline \multirow{2}{*}{$\begin{array}{l}\text { The Nile } \\
\text { alluvium }\end{array}$} & \multirow{2}{*}{1} & $0-20$ & 76.85 & 14.51 & 597.78 & 17.25 & 4.87 & 3.91 & 2.86 \\
\hline & & $20-70$ & 68.40 & 12.94 & 605.07 & 14.73 & 4.03 & 3.72 & 2.54 \\
\hline \multirow{2}{*}{$\begin{array}{l}\text { Fluvio- } \\
\text { lacustrine }\end{array}$} & \multirow{2}{*}{4} & $0-15$ & 71.52 & 15.87 & 578.50 & 15.45 & 5.14 & 4.05 & 2.75 \\
\hline & & $15-70$ & 62.98 & 13.30 & 560.95 & 12.80 & 4.79 & 3.80 & 2.29 \\
\hline \multirow{2}{*}{$\begin{array}{c}\text { Eocene } \\
\text { limestone }\end{array}$} & \multirow{2}{*}{16} & $0-25$ & 65.73 & 5.41 & 559.8 & 6.84 & 1.71 & 1.25 & 1.08 \\
\hline & & $25-70$ & 48.10 & 4.75 & 568.2 & 5.05 & 1.15 & 0.95 & 0.87 \\
\hline \multicolumn{10}{|c|}{ Sandy clay loam soils } \\
\hline \multirow{2}{*}{$\begin{array}{l}\text { Fluvio- } \\
\text { lacustrine }\end{array}$} & \multirow{2}{*}{5} & $0-15$ & 71.55 & 14.05 & 378.90 & 13.75 & 4.25 & 3.20 & 2.48 \\
\hline & & $15-70$ & 69.80 & 13.60 & 396.75 & 11.90 & 3.87 & 2.89 & 2.20 \\
\hline \multirow{6}{*}{$\begin{array}{c}\text { Eocene } \\
\text { limestone }\end{array}$} & \multirow{2}{*}{14} & $0-20$ & 37.91 & 7.15 & 310.42 & 6.65 & 1.90 & 1.42 & 1.10 \\
\hline & & $20-65$ & 28.60 & 6.02 & 291.80 & 5.01 & 1.25 & 0.90 & 0.85 \\
\hline & \multirow{2}{*}{30} & $0-10$ & 32.35 & 5.10 & 300.97 & 4.70 & 1.12 & 0.97 & 0.80 \\
\hline & & $10-55$ & 24.70 & 4.73 & 312.50 & 4.05 & 0.95 & 0.80 & 0.73 \\
\hline & \multirow{2}{*}{41} & $0-15$ & 27.45 & 5.00 & 275.66 & 4.10 & 1.00 & 0.79 & 0.68 \\
\hline & & $15-45$ & 20.93 & 3.80 & 219.75 & 3.67 & 0.70 & 0.65 & 0.61 \\
\hline \multirow{2}{*}{$\begin{array}{l}\text { The Nile } \\
\text { alluvium }\end{array}$} & \multirow{2}{*}{47} & $0-30$ & 59.80 & 12.55 & 347.80 & 10.25 & 2.90 & 2.30 & 2.18 \\
\hline & & $30-70$ & 48.95 & 9.80 & 301.37 & 9.80 & 2.55 & 2.00 & 1.79 \\
\hline \multicolumn{10}{|c|}{ Loamy sand and sandy loam soils } \\
\hline \multirow{2}{*}{$\begin{array}{l}\text { The Nile } \\
\text { alluvium }\end{array}$} & \multirow{2}{*}{6} & $0-25$ & 45.40 & 9.75 & 240.59 & 8.60 & 2.18 & 1.95 & 1.15 \\
\hline & & $25-70$ & 41.05 & 8.90 & 269.72 & 7.15 & 1.90 & 1.43 & 1.05 \\
\hline \multirow{2}{*}{$\begin{array}{l}\text { Fluvio- } \\
\text { lacustrine }\end{array}$} & 12 & $0-30$ & 52.90 & 9.55 & 260.63 & 9.10 & 2.25 & 2.05 & 1.25 \\
\hline & 12 & $30-70$ & 47.75 & 9.03 & 285.40 & 8.45 & 2.00 & 1.80 & 1.19 \\
\hline & & $0-25$ & 28.30 & 6.70 & 120.85 & 6.20 & 1.60 & 1.02 & 0.88 \\
\hline & 21 & $25-70$ & 15.81 & 5.92 & 98.56 & 5.75 & 1.45 & 0.90 & 0.73 \\
\hline Eocene & 31 & $0-10$ & 24.90 & 4.50 & 112.35 & 4.90 & 1.10 & 0.80 & 0.65 \\
\hline limestone & 31 & $10-40$ & 18.75 & 3.87 & 90.81 & 4.15 & 0.94 & 0.72 & 0.58 \\
\hline & 46 & $0-15$ & 20.50 & 3.84 & 74.25 & 3.40 & 0.87 & 059 & 0.43 \\
\hline & 40 & $15-50$ & 15.75 & 3.17 & 60.90 & 3.15 & 0.75 & 0.50 & 0.30 \\
\hline & & & & & dy soils & & & & \\
\hline Desert & 10 & $0-20$ & 17.35 & 3.70 & 39.60 & 3.05 & 0.80 & 0.72 & 0.68 \\
\hline formation & 10 & $20-70$ & 14.20 & 3.25 & 32.85 & 2.80 & 0.70 & 0.64 & 0.54 \\
\hline & 23 & $0-25$ & 15.90 & 3.20 & 41.40 & 3.71 & 0.73 & 0.62 & 0.57 \\
\hline Eocene & 23 & $25-70$ & 13.75 & 2.85 & 35.65 & 3.40 & 0.60 & 0.49 & 0.42 \\
\hline limestone & & $0-30$ & 19.68 & 2.97 & 45.88 & 3.10 & 0.90 & 0.47 & 0.48 \\
\hline & 28 & $30-55$ & 15.34 & 2.65 & 40.20 & 2.55 & 0.79 & 0.32 & 0.35 \\
\hline
\end{tabular}

As discussed before, the greatest soil organic matter content is associated with the clayey Nile alluvial soils (soil site No. 1) vs a very low one in the newly cultivated desert soil siliceous in nature (aeolian deposit of soil site No. 10). In between, it becomes soils developed on the fluvio-lacustrine and Eocene limestone as a parent material.

Meanwhile, the soil inorganic component, which it consists a major portion of soil constituents, is mainly dominated by quartz and clay minerals in the relatively coarse and fine textures soils, respectively. In addition, a pronounced content for each of amorphous materials and lime particles are found in the fine fraction of the Nile alluvial soils and in the different soil mechanical fractions of soils developed on the Eocene limestone, respectively.

The aforementioned discussion could be emphasized by the statistical analysis, Table (6), which showed positive and highly significant correlations between the studied plant nutrients of N, P, K, Fe, Mn, $\mathrm{Zn}$ and $\mathrm{Cu}$ and each of silt fraction, clay fraction and organic matter $\%$ as a soil constituent, besides $\mathrm{N}$ only

Fayoum J. Agric. Res. \& Dev., Vol.24, No.2, July, 2010 


\section{SIGNIFICANCE OF INHERITED SOIL PEDOGENIC ASPECTS .... 54}

with the ECe value. The reverse was true for sand fraction, ECe value and $\mathrm{CaCO}_{3}$ $\%$. That is true, since sand fraction, $\mathrm{ECe}$ and $\mathrm{CaCO}_{3}$ content are of lack nutrientbearing minerals. El-Sayed (2009) came to the same conclusion.

Table (6); Simple correlation coefficients between some soil components and total nutrient contents ( $\mathrm{mg} \mathrm{kg}^{-1}$ soil) in the studied soils.

\begin{tabular}{|c|c|c|c|c|c|c|}
\hline \multirow{2}{*}{ Nutrient } & \multicolumn{3}{|c|}{ Particle size distribution $\%$} & \multirow{2}{*}{$\begin{array}{c}\mathrm{ECe} \\
\left(\mathrm{dS} \mathrm{m} \mathrm{m}^{-1}\right)\end{array}$} & \multirow{2}{*}{$\begin{array}{l}\text { Organic } \\
\text { matter } \%\end{array}$} & \multirow{2}{*}{$\begin{array}{c}\mathrm{CaCO}_{3} \\
\%\end{array}$} \\
\hline & Sand & Silt & Clay & & & \\
\hline $\mathrm{N}$ & $-0.774 * *$ & $0.559 * *$ & $0.807 * *$ & $0.515 * *$ & $0.937 * *$ & $-0.547 * *$ \\
\hline $\mathrm{P}$ & $-0.921 * *$ & $0.754 * *$ & $0.926 * *$ & $-0.353 *$ & $0.909 * *$ & $-0.493 * *$ \\
\hline $\mathrm{K}$ & $-0.901 * *$ & $0.677 * *$ & $0.930 * *$ & $-0.377 *$ & $0.882 * *$ & $-0.366^{*}$ \\
\hline $\mathrm{Fe}$ & $-0.902 * *$ & $0.731 * *$ & $0.909 * *$ & $-0.453 * *$ & $0.850 * *$ & $-0.488 * *$ \\
\hline $\mathrm{Mn}$ & $-0.939 * *$ & $0.742 * *$ & $0.954 * *$ & $-0.476 * *$ & $0.848 * *$ & $-0.515^{* *}$ \\
\hline $\mathrm{Zn}$ & $-0.930 * *$ & $0.752 * *$ & $0.938 * *$ & $-0.488 * *$ & $0.848 * *$ & $-0.507 * *$ \\
\hline $\mathrm{Cu}$ & $-0.950 * *$ & $0.773 * *$ & $0.956 * *$ & $-0.363^{*}$ & $0.853 * *$ & $-0.478 * *$ \\
\hline
\end{tabular}

The statistical multiple regression equations, which showed the contribution of almost stable and unstable soil components in relation to the total nutrient contents are presented as follows:

a. Stable soil components:

Total $\mathrm{N}=382.39-9.44$ silt +25.37 clay $-12.38 \mathrm{CaCO}_{3}$

Total $\mathrm{P}=124.74+3.60$ silt +10.24 clay $-2.67 \mathrm{CaCO}_{3}$

$\left(\mathrm{R}^{2}=0.779^{* * *}\right)$

Total K

$=4195.41-42.26$ silt +220.71 clay $-40.20 \mathrm{CaCO}_{3}$

Total Fe $=5869.11-209.11$ silt +763.04 clay $-219.24 \mathrm{CaCO}_{3}$

Total Mn $=44.264-0.46$ silt +5.15 clay $-0.773 \mathrm{CaCO}_{3}$

Total $\mathrm{Zn}=13.94-0.384$ silt +1.600 clay $-0.205 \mathrm{CaCO}_{3}$

Total $\mathrm{Cu}=15.62-0.28$ silt +0.97 clay $-0.12 \mathrm{CaCO}_{3}$

b. Unstable soil components:

Total $\mathrm{N}=64.45-0.82 \mathrm{ECe}+625.27$ organic matter

Total $\mathrm{P}=132.26+0.57 \mathrm{ECe}+266.80$ organic matter

Total K $=3997.01+5.592 \mathrm{ECe}+4527.18$ organic matter

Total Fe $=9520.73-23.73 \mathrm{ECe}+17019.67$ organic matter

$\left(\mathrm{R}^{2}=0.889^{* * *}\right)$

$\left(\mathrm{R}^{2}=0.883^{* * *}\right)$

$\left(\mathrm{R}^{2}=0.861 * * *\right)$

$\left(\mathrm{R}^{2}=0.920 * * *\right)$

$\left(\mathrm{R}^{2}=0.883 * * *\right)$

$\left(\mathrm{R}^{2}=0.920^{* * *}\right)$

Total Mn $=58.21+0.27 \mathrm{ECe}+110.99$ organic matter

$\left(\mathrm{R}^{2}=0.946^{* * *}\right)$

$\left(\mathrm{R}^{2}=0.825^{* * *}\right)$

$\left(\mathrm{R}^{2}=0.765 * * *\right)$

$\left(\mathrm{R}^{2}=0.707 * * *\right)$

$\left(\mathrm{R}^{2}=0.711^{* * *}\right)$

Total $\mathrm{Zn}=19.79+0.118 \mathrm{ECe}+37.13$ organic matter

$\left(\mathrm{R}^{2}=0.718 * * *\right)$

Total $\mathrm{Cu}=18.82+0.094 \mathrm{ECe}+23.23$ organic matter

$\left(\mathrm{R}^{2}=0.758 * * *\right)$

c. Stable and unstable soil components: $\begin{aligned} \text { Total } \mathrm{N}= & 96.37-3.62 \text { silt }+7.36 \text { clay }-1.78 \mathrm{CaCO}_{3}+498.54 \\ & \text { organic matter }-0.951 \mathrm{ECe}\end{aligned}(\mathrm{R} 2=0.957 * * *)$

Total P

$=43.75+5.85$ silt +5.66 clay $+0.67 \mathrm{CaCO}_{3}+119.35$ organic matter $-0.65 \mathrm{ECe}$

Total K $\begin{aligned}= & 2856.29+3.88 \text { silt }+55.48 \text { clay }+21.84 \mathrm{CaCO}_{3}+(\mathrm{R} 2=0.933 * * *) \\ & 1536.80 \text { organic matter }-18.34 \mathrm{ECe}\end{aligned}$

Total Fe $=451.232+561.26$ silt +560.14 clay $+141.74 \mathrm{CaCO}_{3}+$ 2874.15 organic matter $-162.86 \mathrm{ECe}$

Total Mn

$\begin{aligned}= & 21.11+1.41 \text { silt }+4.11 \text { clay }-0.36 \mathrm{CaCO}_{3}+22.57 \\ & \text { organic matter }-0.39 \mathrm{ECe}\end{aligned}$

Total Zn

$=4.88+0.70$ silt +1.14 clay $+0.21 \mathrm{CaCO} 3+10.98$ organic matter $-0.11 \mathrm{ECe}$

$\left(\mathrm{R} 2=0.915^{* * *}\right)$

Fayoum J. Agric. Res. \& Dev., Vol.24, No.2, July, 2010 
Total $\mathrm{Cu}$

$$
\begin{aligned}
= & 11.31+0.39 \text { silt }+0.72 \text { clay }+0.05 \mathrm{CaCO}_{3}+6.72(\mathrm{R} 2=0.943 * * *) \\
& \text { organic matter }-0.03 \mathrm{ECe}
\end{aligned}
$$

A stepwise regression, as shown in table (7), indicates that the best contribution as a percentage for each of sand, silt, clay, ECe, organic matter and $\mathrm{CaCO}_{3}$ contents as soil constituents with the total contents of the studied essential plant nutrients. That is confirmed by $\mathrm{R}^{2}$ that is concerned with both constant values and best contribution. The residual fraction expresses the contribution of other factors affect the total nutrient contents, either included in the stepwise regression or out it.

Table (7): Contribution percentages of some soil components for the total nutrient contents $\left(\mathrm{mg} \mathrm{kg}^{-1}\right.$ soil) in the studied soils.

\begin{tabular}{|c|c|c|c|c|c|c|c|}
\hline Soil variable & $\mathrm{N}$ & $\mathrm{P}$ & $\mathrm{K}$ & $\mathrm{Fe}$ & $\mathrm{Mn}$ & $\mathrm{Zn}$ & $\mathrm{Cu}$ \\
\hline Sand & -- & 1.10 & -- & 2.30 & 1.40 & 1.70 & -- \\
\hline Silt & -- & 0.90 & -- & -- & 5.20 & 3.60 & 1.40 \\
\hline Clay & 9.50 & 56.10 & 80.80 & 79.60 & 78.50 & 72.70 & 84.20 \\
\hline ECe & 0.80 & -- & 3.70 & 4.90 & 0.60 & -- & -- \\
\hline Organic matter & 85.50 & 27.80 & 4.50 & -- & 6.90 & 9.80 & 7.10 \\
\hline $\mathrm{CaCO}_{3}$ & -- & 9.50 & 4.80 & 8.90 & 2.80 & 3.50 & 4.20 \\
\hline $\mathrm{R}^{2}$ & 95.80 & 95.4 & 93.8 & 95.70 & 95.40 & 91.30 & 96.90 \\
\hline Residual & 4.20 & 4.6 & 6.20 & 4.30 & 4.60 & 8.70 & 3.10 \\
\hline
\end{tabular}

The obtained results in Table (8) indicate that all the studied available nutrient contents positively correlated at highly significant with each of silt fraction, clay fraction, available water, organic matter content and total content of nutrients as soil variables. The reverse was true for each of sand fraction, bulk density, $\mathrm{ECe}, \mathrm{CaCO}_{3}, \mathrm{pH}$ and ESP.

Table (8); Simple correlation coefficients between some soil variables and available nutrient contents $\left(\mathrm{mg} \mathrm{kg}^{-1}\right.$ soil) in the studied soils.

\begin{tabular}{|c|c|c|c|c|c|c|c|}
\hline Soil variable & $\mathrm{N}$ & $\mathrm{P}$ & $\mathrm{K}$ & $\mathrm{Fe}$ & $\mathrm{Mn}$ & $\mathrm{Zn}$ & $\mathrm{Cu}$ \\
\hline Sand & $-0.817^{* *}$ & $-0.675^{* *}$ & $-0.973^{* *}$ & $-0.726^{* *}$ & $-0.715^{* *}$ & $-0.737^{* *}$ & $-0.757^{* *}$ \\
\hline Silt & $0.647^{* *}$ & $0.563^{* *}$ & $0.814^{* *}$ & $0.618^{* *}$ & $0.570^{* *}$ & $0.598^{* *}$ & $0.619^{* *}$ \\
\hline Clay & $0.829^{* *}$ & $0.673^{* *}$ & $0.970^{* *}$ & $0.719^{* *}$ & $0.723^{* *}$ & $0.741^{* *}$ & $0.760^{* *}$ \\
\hline Bulk density & $-0.905^{* *}$ & $-0.836^{* *}$ & $-0.915^{* *}$ & $-0.890^{* *}$ & $-0.865^{* *}$ & $-0.870^{* *}$ & $-0.884^{* *}$ \\
\hline Available water & $0.915^{* *}$ & $0.896^{* *}$ & $0.831^{* *}$ & $0.868^{* *}$ & $0.832^{* *}$ & $0.855^{* *}$ & $0.888^{* *}$ \\
\hline $\mathrm{ECe}$ & $-0.448^{*}$ & $-0.470^{* *}$ & $-0.485^{* *}$ & $-0.464^{* *}$ & $-0.460^{* *}$ & $-0.453^{* *}$ & $-0.451^{* *}$ \\
\hline Organic matter & $0.971^{* *}$ & $0.929^{* *}$ & $0.820^{* *}$ & $0.878^{* *}$ & $0.940^{* *}$ & $0.943^{* *}$ & $0.950^{* *}$ \\
\hline $\mathrm{CaCO}_{3}$ & $-0.487^{* *}$ & $-0.561^{* *}$ & $-0.490^{* *}$ & $-0.509^{* *}$ & $-0.494^{* *}$ & $-0.539^{* *}$ & $-0.551^{* *}$ \\
\hline $\mathrm{pH}$ & $-0.380^{*}$ & $-0.555^{* *}$ & $-0.453^{*}$ & $-0.482^{* *}$ & $-0.545^{* *}$ & $-0.487^{* *}$ & $-0.486^{* *}$ \\
\hline $\mathrm{ESP}$ & $-0.492^{* *}$ & $-0.598^{* *}$ & $-0.485^{* *}$ & $-0.548^{* *}$ & $-0.488^{* *}$ & $-0.526^{* *}$ & $-0.539^{* *}$ \\
\hline Total content & $0.973^{* *}$ & $0.832^{* *}$ & $0.943^{* *}$ & $0.790^{* *}$ & $0.794^{* *}$ & $0.8 .26^{* *}$ & $0.860^{* *}$ \\
\hline
\end{tabular}

These findings are in harmony with those were discussed before in a part of available nutrient contents as related to the studied soil variables, as well as with the results obtained by Awadalla et al. (2007). The statistical multiple regression equations, which showed the contribution of almost stable and unstable soil components in relation to the available nutrient contents, are presented as follows:

Fayoum J. Agric. Res. \& Dev., Vol.24, No.2, July, 2010 
a. Stable soil components:

$$
\begin{aligned}
& \text { Available } \mathrm{N}=25.05+0.11 \text { silt }+0.83 \text { clay }-0.38 \mathrm{CaCO}_{3} \\
& \text { Available } \mathrm{P}=5.88+0.07 \text { silt }+0.11 \text { clay }-0.10 \mathrm{CaCO}_{3} \\
& \text { Available } \mathrm{K}=10.64+4.33 \text { silt }+8.41 \text { clay }-0.98 \mathrm{CaCO}_{3} \\
& \text { Available } \mathrm{Fe}=4.74+0.09 \text { silt }+0.11 \text { clay }-0.09 \mathrm{CaCO}_{3} \\
& \text { Available } \mathrm{Mn}=1.30+0.01 \text { silt }+0.05 \text { clay }-0.03 \mathrm{CaCO}_{3} \\
& \text { Available } \mathrm{Zn}=1.01+0.01 \text { silt }+0.04 \text { clay }-0.03 \mathrm{CaCO}_{3} \\
& \text { Available } \mathrm{Cu}=0.793+0.01 \text { silt }+0.02 \text { clay }-0.02 \mathrm{CaCO}_{3} \\
& \text { b. Unstable soil components: } \\
& \text { Available } \mathrm{N}=17.22+10.54 \mathrm{OM}-0.07 \mathrm{pH}+0.03 \mathrm{ECe}+0.02 \text { Total }\left(\mathrm{R}^{2}=0.954^{* * *}\right)
\end{aligned}
$$$$
\text { Available } \mathrm{P}=23.58+3.60 \mathrm{OM}-2.48 \mathrm{pH}+0.01 \mathrm{ECe}+0.02 \text { Total } \quad\left(\mathrm{R}^{2}=0.892 * * *\right)
$$$$
\text { Available } \mathrm{K}=-68.63+11.53 \mathrm{OM}-4.90 \mathrm{pH}+0.74 \mathrm{ECe}+0.04 \text { Total }\left(\mathrm{R}^{2}=0.899 * * *\right)
$$$$
\text { Available } \mathrm{Fe}=20.93+2.74 \mathrm{OM}-2.20 \mathrm{pH}+0.01 \mathrm{ECe}+0.00 \text { Total } \quad\left(\mathrm{R}^{2}=0.781 * * *\right)
$$$$
\text { Available } \mathrm{Mn}=2.90+1.44 \mathrm{OM}-0.28 \mathrm{pH}+0.001 \mathrm{ECe}+0.00 \text { Total } \quad\left(\mathrm{R}^{2}=0.872 * * *\right)
$$$$
\text { Available } \mathrm{Zn}=4.382+0.96 \mathrm{OM}-0.50 \mathrm{pH}+0.002 \mathrm{ECe}+0.01 \text { Total }\left(\mathrm{R}^{2}=0.901 * * *\right)
$$$$
\text { Available } \mathrm{Cu}=2.80+0.61 \mathrm{OM}-0.31 \mathrm{pH}+0.001 \mathrm{ECe}+0.01 \text { Total } \quad\left(\mathrm{R}^{2}=0.922 * * *\right)
$$$$
\text { c. Stable and unstable soil components: }
$$

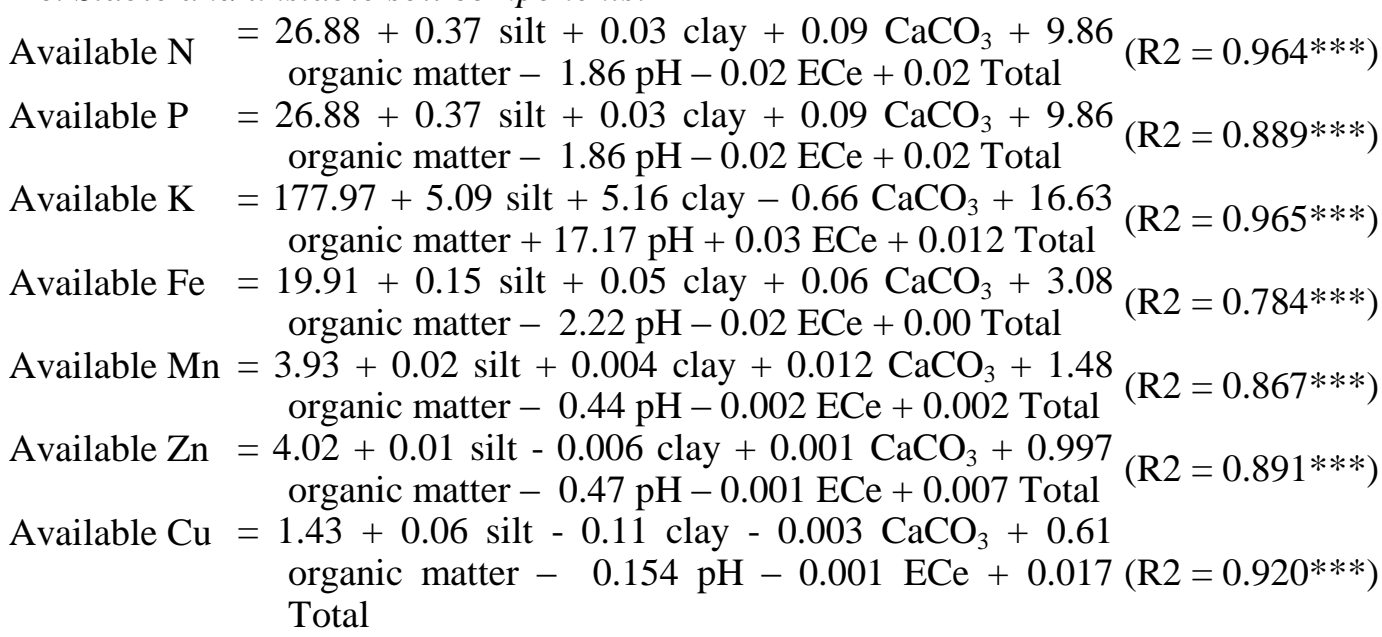

A stepwise regression, as shown in table (9), indicates that the best contribution as a percentage for each of sand, silt, clay, bulk density, available water, ECe, organic matter, $\mathrm{CaCO}_{3}, \mathrm{pH}$, ESP and total content of nutrients as soil variable with the available contents of the studied essential plant nutrients. That is confirmed by $\mathrm{R}^{2}$ that is concerned with both constant values and best contribution. The residual fraction expresses the contribution of other factors affect the total nutrient contents, either included in the stepwise regression or out it. 
Table (9): Contribution percentages of some soil components for the available nutrient contents ( $\mathrm{mg} \mathrm{kg}^{-1}$ soil) in the studied soils.

\begin{tabular}{|c|c|c|c|c|c|c|c|}
\hline Soil variable & N & P & K & Fe & Mn & Zn & Cu \\
\hline Sand & -- & -- & 5.60 & -- & -- & 5.30 & -- \\
\hline Silt & -- & -- & 0.60 & 1.50 & -- & 0.50 & -- \\
\hline Clay & -- & 2.70 & 86.50 & 70.60 & 2.40 & 1.80 & 5.30 \\
\hline Bulk density & -- & 0.80 & -- & -- & -- & 0.50 & 1.20 \\
\hline Available water & 1.90 & 1.40 & -- & -- & -- & -- & 1.60 \\
\hline ECe & -- & -- & -- & -- & -- & -- & -- \\
\hline Organic matter & 2.60 & 78.20 & -- & -- & 72.60 & 74.80 & 70.30 \\
\hline $\mathrm{CaCO}_{3}$ & -- & 4.10 & 1.80 & 6.50 & 5.30 & 3.20 & 6.50 \\
\hline pH & 0.40 & 3.30 & -- & 6.70 & 0.60 & 1.10 & 1.80 \\
\hline ESP & -- & -- & -- & -- & -- & -- & -- \\
\hline Total content & 92.40 & -- & 2.30 & -- & 7.10 & 1.30 & 4.70 \\
\hline $\mathrm{R}^{2}$ & 97.30 & 90.50 & 96.80 & 85.30 & 88.00 & 88.50 & 91.40 \\
\hline Residual & 2.70 & 9.50 & 3.20 & 14.70 & 12.00 & 11.50 & 6.60 \\
\hline
\end{tabular}

\section{Plant parameters as affected by soil relationships:}

The positive or negative reflections of the aforementioned soil relationships on the plant parameters of grown wheat (Sakha $93 \mathrm{cv}$.) at both vegetative growth and harvest stages for selected nine soil sites are presented in Tables (10-13).

\section{a. Vegetative growth parameters:}

Growth characters of grown wheat plants in the studied soil sites could be identified through plant height, dry weight, No. of tillers, leaf area, chlorophyll content of a \& b and nutrients uptake, as shown in Tables (10 and 11). The data obtained showed that the magnitudes of the increments of these parameters are differed from a soil site to another, where these characters went on a gradual increase when the soil variables tend towards the best conditions. Such favourable conditions are characterized by a pronounced content of nutrient-bearing minerals as well as factors that are enhancing more released nutrients and their solubilization from both sources of native or added as well the favourable biological conditions that are keeping them in available forms for extended period and their mobility for uptake by plant roots.

That means the fertile soil media, such as a fluvial one of site No. 1, are characterized by best soil properties as well as being considered as a storehouse for nutrients with easily mobile or available to uptake by plant roots. On the other hand, it is evident that the relative high active $\mathrm{CaCO}_{3}$ content in soil site No. 16 or high sand fraction in soil site No. 10, that are characterized by calcareous or siliceous in nature, led to restrict the availability of some macro- and micronutrients. This was clearly when comparing between the studied two soil sites of 16 and 1 within that same texture grade, since the high $\mathrm{CaCO}_{3}$ soil of site No. 16 exhibited a lesser extent in the studied vegetative growth characters as compared to the low $\mathrm{CaCO}_{3}$ one of site No. 1. Concerning soil site No. 10, the dominance of sand fraction means that this soil is not only poorer in nutrient-bearing mineral but also it is not able to retain available nutrients or moisture needs to the grown plants. Data that pertaining the beneficial effects of soil properties on leaves contents of nutrients $(\mathrm{N}, \mathrm{P}, \mathrm{K}, \mathrm{Fe}, \mathrm{Mn}, \mathrm{Zn}$ and $\mathrm{Cu})$ determined at 70 days after sowing for the grown wheat plants are presented in Table (11), and showed a progressive increase in their contents as the soils have no restrictive factors. 
SIGNIFICANCE OF INHERITED SOIL PEDOGENIC ASPECTS ..... 58

Table (10): Vegetative growth parameters of wheat plants grown on the representative soil sites.

\begin{tabular}{|c|c|c|c|c|c|c|c|c|}
\hline Soil type & $\begin{array}{c}\text { Parent } \\
\text { material }\end{array}$ & $\begin{array}{c}\text { Soil site } \\
\text { No. }\end{array}$ & $\begin{array}{l}\text { Plant } \\
\text { height } \\
(\mathrm{cm})\end{array}$ & $\begin{array}{c}\text { Dry weight } \\
\operatorname{plant}^{-1}(\mathrm{~g})\end{array}$ & $\begin{array}{c}\text { Tiller Nos. } \\
\text { plant }^{-1}\end{array}$ & $\begin{array}{c}\text { Leaf area } \\
\text { plant }^{-1}\left(\mathrm{~cm}^{2}\right)\end{array}$ & \begin{tabular}{|c|}
$\begin{array}{c}\text { Chlorophyll a } \\
\text { (mg g-1 fresh } \\
\text { weight) }\end{array}$ \\
\end{tabular} & $\begin{array}{c}\text { Chlorophyll b } \\
\text { (mg g } \mathrm{g}^{-1} \text { fresh } \\
\text { weight) }\end{array}$ \\
\hline \multirow{3}{*}{ Clay } & $\begin{array}{l}\text { The Nile } \\
\text { alluvium }\end{array}$ & 1 & 107.45 & 14.70 & 7.40 & 37.65 & 1.90 & 1.35 \\
\hline & $\begin{array}{c}\text { Fluvio- } \\
\text { lacustrine }\end{array}$ & 4 & 112.82 & 15.95 & 8.17 & 39.70 & 2.10 & 1.50 \\
\hline & $\begin{array}{c}\text { Eocene } \\
\text { limestone }\end{array}$ & 16 & 91.55 & 10.90 & 5.50 & 31.55 & 1.39 & 0.95 \\
\hline \multirow{2}{*}{$\begin{array}{l}\text { Sandy } \\
\text { clay } \\
\text { loam }\end{array}$} & $\begin{array}{c}\text { Fluvio- } \\
\text { lacustrine }\end{array}$ & 5 & 111.60 & 15.80 & 7.95 & 39.35 & 2.04 & 1.47 \\
\hline & $\begin{array}{l}\text { The Nile } \\
\text { alluvium }\end{array}$ & 47 & 102.70 & 13.55 & 6.80 & 35.84 & 1.75 & 1.23 \\
\hline \multirow{3}{*}{$\begin{array}{c}\text { Loamy } \\
\text { sand } \\
\text { or sandy } \\
\text { loam }\end{array}$} & $\begin{array}{l}\text { The Nile } \\
\text { alluvium }\end{array}$ & 6 & 97.25 & 12.49 & 6.25 & 33.90 & 1.60 & 1.12 \\
\hline & \begin{tabular}{|c|}
$\begin{array}{c}\text { Fluvio- } \\
\text { lacustrine }\end{array}$ \\
\end{tabular} & 12 & 95.93 & 12.05 & 6.10 & 33.67 & 1.54 & 1.07 \\
\hline & $\begin{array}{c}\text { Eocene } \\
\text { limestone }\end{array}$ & 21 & 87.40 & 9.85 & 4.97 & 29.75 & 1.25 & 0.85 \\
\hline Sand & $\begin{array}{c}\text { Desert } \\
\text { formation }\end{array}$ & 10 & 82.25 & 7.90 & 4.35 & 26.50 & 1.12 & 0.75 \\
\hline \multicolumn{3}{|c|}{ L.S.D. at 0.05} & 2.91 & 0.79 & 0.47 & 1.64 & 0.10 & 0.08 \\
\hline
\end{tabular}

Table (11): Nutrients uptake by wheat plants grown on the representative soil sites after $\mathbf{7 0}$ days from planting.

\begin{tabular}{|c|c|c|c|c|c|c|c|c|c|}
\hline \multirow{2}{*}{ Soil type } & \multirow{2}{*}{$\begin{array}{c}\text { Parent } \\
\text { material }\end{array}$} & \multirow{2}{*}{$\begin{array}{c}\text { Soil site } \\
\text { No. }\end{array}$} & \multicolumn{3}{|c|}{ Macronutrients \% } & \multicolumn{4}{|c|}{ Micronutrients $\left(\mathrm{mg} \mathrm{kg}^{-1}\right)$} \\
\hline & & & $\mathrm{N}$ & $\mathrm{P}$ & $\mathrm{K}$ & $\mathrm{Fe}$ & $\mathrm{Mn}$ & $\mathrm{Zn}$ & $\mathrm{Cu}$ \\
\hline \multirow{3}{*}{ Clay } & $\begin{array}{l}\text { The Nile } \\
\text { alluvium }\end{array}$ & 1 & 3.95 & 0.52 & 3.75 & 105.70 & 79.10 & 59.45 & 16.80 \\
\hline & $\begin{array}{c}\text { Fluvio- } \\
\text { lacustrine }\end{array}$ & 4 & 4.35 & 0.60 & 3.98 & 119.50 & 90.95 & 67.80 & 18.35 \\
\hline & $\begin{array}{c}\text { Eocene } \\
\text { limestone }\end{array}$ & 16 & 3.20 & 0.31 & 3.20 & 70.10 & 54.70 & 40.25 & 12.40 \\
\hline \multirow{2}{*}{$\begin{array}{l}\text { Sandy clay } \\
\text { loam }\end{array}$} & $\begin{array}{c}\text { Fluvio- } \\
\text { lacustrine }\end{array}$ & 5 & 4.25 & 0.58 & 3.92 & 117.35 & 88.80 & 65.30 & 18.07 \\
\hline & $\begin{array}{l}\begin{array}{c}\text { The Nile } \\
\text { alluvium }\end{array} \\
\end{array}$ & 47 & 3.70 & 0.45 & 3.55 & 94.75 & 71.60 & 53.85 & 15.35 \\
\hline \multirow{3}{*}{$\begin{array}{l}\text { Loamy } \\
\text { sand } \\
\text { or sandy } \\
\text { loam }\end{array}$} & $\begin{array}{l}\text { The Nile } \\
\text { alluvium }\end{array}$ & 6 & 3.50 & 0.39 & 3.40 & 83.20 & 63.10 & 47.10 & 13.90 \\
\hline & $\begin{array}{c}\begin{array}{c}\text { Fluvio- } \\
\text { lacustrine }\end{array} \\
\end{array}$ & 12 & 3.43 & 0.37 & 3.34 & 81.95 & 62.35 & 46.73 & 13.65 \\
\hline & $\begin{array}{c}\text { Eocene } \\
\text { limestone }\end{array}$ & 21 & 2.95 & 0.26 & 2.95 & 59.40 & 46.90 & 34.60 & 10.70 \\
\hline Sand & $\begin{array}{c}\text { Desert } \\
\text { formation }\end{array}$ & 10 & 2.67 & 0.21 & 2.74 & 48.80 & 39.55 & 27.45 & 8.90 \\
\hline \multicolumn{3}{|c|}{ L.S.D. at 0.05} & 0.13 & 0.05 & 0.10 & 9.50 & 7.21 & 5.20 & 1.16 \\
\hline
\end{tabular}

\section{a. Plant parameters at harvest stage:}

The achieved results indicate that the obtained soil relationships are exerted a great beneficial effect on the studied plant parameters at harvest stage of wheat crop in soils characterized by best properties, as shown in Tables (12 and 13).

Fayoum J. Agric. Res. \& Dev., Vol.24, No.2, July, 2010 
Abdel Nasser A.A. Abdel Hafeez, et al.

Table (12): Spike parameters and weight of 100 grains of wheat plants grown on the representative soil sites.

\begin{tabular}{|c|c|c|c|c|c|c|c|c|}
\hline \multirow[b]{2}{*}{ Soil type } & \multirow[b]{2}{*}{$\begin{array}{l}\text { Parent } \\
\text { material }\end{array}$} & \multirow[b]{2}{*}{$\begin{array}{l}\text { Soil site } \\
\text { No. }\end{array}$} & \multicolumn{5}{|c|}{ Wheat spike parameters } & \multirow[b]{2}{*}{$\begin{array}{l}1000 \text { grain } \\
\text { weight }(\mathrm{g})\end{array}$} \\
\hline & & & $\begin{array}{l}\text { Length } \\
(\mathrm{cm})\end{array}$ & Weight $(\mathrm{g})$ & Nos. $\mathrm{m}^{-2}$ & Grain Nos. & $\begin{array}{c}\text { Grain } \\
\text { weight }(\mathrm{g})\end{array}$ & \\
\hline \multirow{3}{*}{ Clay } & $\begin{array}{l}\text { The Nile } \\
\text { alluvium }\end{array}$ & 1 & 14.58 & 5.75 & 372 & 59 & 4.20 & 46.95 \\
\hline & $\begin{array}{c}\text { Fluvio- } \\
\text { lacustrine }\end{array}$ & 4 & 15.62 & 6.35 & 398 & 65 & 4.59 & 49.80 \\
\hline & $\begin{array}{c}\text { Eocene } \\
\text { limestone }\end{array}$ & 16 & 11.80 & 4.27 & 301 & 48 & 3.31 & 38.72 \\
\hline \multirow{2}{*}{$\begin{array}{c}\text { Sandy } \\
\text { clay loam }\end{array}$} & $\begin{array}{c}\text { Fluvio- } \\
\text { lacustrine }\end{array}$ & 5 & 15.45 & 6.20 & 393 & 64 & 4.52 & 49.50 \\
\hline & $\begin{array}{l}\text { The Nile } \\
\text { alluvium }\end{array}$ & 47 & 13.77 & 5.32 & 350 & 56 & 3.95 & 44.47 \\
\hline \multirow{3}{*}{$\begin{array}{l}\text { Loamy } \\
\text { sand } \\
\text { or sandy } \\
\text { loam }\end{array}$} & $\begin{array}{l}\text { The Nile } \\
\text { alluvium }\end{array}$ & 6 & 12.90 & 4.90 & 329 & 53 & 3.65 & 41.95 \\
\hline & $\begin{array}{l}\text { Fluvio- } \\
\text { lacustrine }\end{array}$ & 12 & 12.68 & 4.75 & 325 & 51 & 3.58 & 41.40 \\
\hline & $\begin{array}{c}\text { Eocene } \\
\text { limestone }\end{array}$ & 21 & 10.95 & 3.85 & 277 & 45 & 3.00 & 35.05 \\
\hline Sand & $\begin{array}{c}\text { Desert } \\
\text { formation }\end{array}$ & 10 & 8.70 & 2.94 & 245 & 39 & 2.30 & 32.94 \\
\hline \multicolumn{3}{|c|}{ L.S.D. at 0.05} & 0.73 & 0.35 & 17.50 & 2.70 & 0.24 & 2.20 \\
\hline
\end{tabular}

Table (13): Grain chemical constituents and biological yield of wheat plants grown on the representative soil sites.

\begin{tabular}{|c|c|c|c|c|c|c|c|c|}
\hline \multirow[b]{2}{*}{$\begin{array}{l}\text { Soil } \\
\text { type }\end{array}$} & \multirow[b]{2}{*}{$\begin{array}{l}\text { Parent } \\
\text { material }\end{array}$} & \multirow{2}{*}{$\begin{array}{l}\text { Soil } \\
\text { site } \\
\text { No. }\end{array}$} & \multicolumn{4}{|c|}{ Grain chemical constituents } & \multicolumn{2}{|c|}{$\begin{array}{c}\text { Biological yield } \\
\left(\mathrm{kg} \mathrm{fed}^{-1}\right)\end{array}$} \\
\hline & & & $\begin{array}{c}\text { Protein } \\
\%\end{array}$ & \begin{tabular}{|c|} 
Total \\
carbohydrates \\
$\%$
\end{tabular} & $\begin{array}{l}\text { Total amino } \\
\text { acids ( } \mathrm{mg} \mathrm{g}^{-1} \\
\text { fresh weight) }\end{array}$ & $\begin{array}{c}\text { Total sugars } \\
\%\end{array}$ & Straw & Grain \\
\hline \multirow{3}{*}{ Clay } & $\begin{array}{l}\text { The Nile } \\
\text { alluvium }\end{array}$ & 1 & 11.45 & 28.50 & 19.70 & 12.40 & 4483 & 2765 \\
\hline & $\begin{array}{c}\text { Fluvio- } \\
\text { lacustrine }\end{array}$ & 4 & 12.70 & 29.95 & 22.55 & 13.70 & 4559 & 2873 \\
\hline & $\begin{array}{c}\text { Eocene } \\
\text { limestone }\end{array}$ & 16 & 8.95 & 24.60 & 14.90 & 9.55 & 3315 & 2137 \\
\hline \multirow{2}{*}{$\begin{array}{l}\text { Sandy } \\
\text { clay } \\
\text { loam }\end{array}$} & $\begin{array}{c}\text { Fluvio- } \\
\text { lacustrine }\end{array}$ & 5 & 12.30 & 29.65 & 21.60 & 13.25 & 4598 & 2641 \\
\hline & $\begin{array}{l}\text { The Nile } \\
\text { alluvium }\end{array}$ & 47 & 10.70 & 27.30 & 17.78 & 11.57 & 4112 & 2534 \\
\hline \multirow{3}{*}{$\begin{array}{l}\text { Loamy } \\
\text { sand } \\
\text { or } \\
\text { sandy } \\
\text { loam }\end{array}$} & $\begin{array}{l}\text { The Nile } \\
\text { alluvium }\end{array}$ & 6 & 9.85 & 26.05 & 16.40 & 10.60 & 3960 & 2492 \\
\hline & $\begin{array}{c}\text { Fluvio- } \\
\text { lacustrine }\end{array}$ & 12 & 9.78 & 25.80 & 16.15 & 10.35 & 3678 & 2295 \\
\hline & $\begin{array}{c}\text { Eocene } \\
\text { limestone }\end{array}$ & 21 & 8.04 & 23.45 & 13.65 & 8.70 & 2995 & 2082 \\
\hline Sand & $\begin{array}{c}\text { Desert } \\
\text { formation }\end{array}$ & 10 & 7.05 & 20.80 & 10.87 & 7.35 & 2684 & 1751 \\
\hline \multicolumn{3}{|c|}{ L.S.D. at 0.05} & 0.79 & 1.01 & 1.15 & 0.62 & 211 & 137 \\
\hline
\end{tabular}

The obtained results revealed clearly that, the favourable parameters of plant growth as related to the best soil relationships, are positively reflected on the plant parameters at harvest stage, i.e., wheat spike characters, weight of 1000 grain, grain quality (protein , carbohydrate, amino acids, sugar contents) and biological yield (grain and straw). Noteworthy that the best fertility status of the fluvial soil of site No. 1 has a progressive increase in the plant parameters at harvest stage as compared to that of similar texture at soil site No. 16. The

Fayoum J. Agric. Res. \& Dev., Vol.24, No.2, July, 2010 
noticeable reverse trend at the later soil site was associated with a more pronounced increase in $\mathrm{CaCO}_{3}$ content and its restrictive effect on the soil nutrients availability and uptake by plants. Such observation was also noticed at soil site No. 10 that is characterized by siliceous in nature, and in turn it is negatively reflected on development of plant parameters due to it is poorer in nutrient-bearing minerals, available water range, and the released available nutrients needs to the grown plants.

Like as in the most harvest traits showed markedly increases in crop yield and its components due to the increases in spike numbers $/ \mathrm{m}^{2}$ and number of grains/spike rather than the increase in 1000 grain weight, which seems to be less affected with the prevailing soil conditions. Straw and grain yields showed also increments amounted to more than 40 and $26 \%$ in the Nile alluvial clayey soil (soil site no. 1) over the same texture calcareous in nature (soil site No. 16). The corresponding relative increase percentages were more than 40 and $36 \%$ over the siliceous sand soil of soil site No. 10. The increment of grain yield was confirmed by the increases in spike numbers $/ \mathrm{m}^{2}$ and number of grains/spike rather. Whereas, the increment in straw yield represents a function of plant height as a major magnitude and magnitude tillering capacity a minor as a minor one. Undoubtedly, the positive response of plan parameters at both the vegetative growth and harvest stages is more attributed to the beneficial effects of physico-chemical, hydrological, chemical, fertility and biological characteristics of the soils under investigation.

\section{REFERENCES:}

Abbas, H.H.; Camilia Y. El Dewiny; H.H. Hassuna and Ghada A. Abd El Kader 2003. Total and DTPA extractable micronutrients as correlated to some soil properties in Kaluobia Governorate. Egypt. J. Soil Sci., 43 (4): 509-528.

Abdel Hafeez, A.A.A.; S.A.M. Moussa and Y.R.A. Soliman 2008. Soil depositional mode, fertility status and suitability for spesific crops of physiographic-soil units at the desert belt between El-Fayoum depression and the Nile Valley, Egypt. Egypt J. Soil Sci., 48 (under Press).

Abd El Hamid, M.A. 1983. Mineralogy and chemistry of potassium in some new reclaimed soils of Egypt. Ph. D. Thesis, Fac. of Agric., Cairo Univ., Egypt.

Abd El-Latif, N.O.F. 2005. Site-specific soil fertility management: A case study in El-Fayoum Governorate. Ph. D. Thesis, Fac. of Agric., Alexandria Univ., Egypt.

A.O.A.C. (1995).Official Methods of Analysis of Association Official Agricultural Chemist. Franklin Station., Washington D.C.

Assal, M.H. 1981. The mineralogy of soil potassium. Ph. D. Thesis, Fac. of Agric., Zagazig Univ., Egypt.

Awadalla, A.A. 1993. Mineralogical and physical properties of some soils at El Fayoum Governorate and their relation to soil fertility. M. Sc. Thesis, Fac. of Agric. at El Fayoum, Cairo Univ., Egypt.

Awadalla, A.A.; A.A.A. Wahdan and S.A.M. Mousa 2007. Originated soil material constituents as a function of supplying power capacity for nutrients at the main sediments of El-Fayoum depression, Egypt. Fayoum J. Agric. Res. \& Dev., 21 (1): 78-97.

Basyouny, E.A. (2005): Effect of chelated micronutrients combined with sulphur or organic manures on wheat production grown on calcareous soil. Egypt. J. Appl. Sci., 20 (9): 375-387.

Fayoum J. Agric. Res. \& Dev., Vol.24, No.2, July, 2010 
Batey, T. (1990). Control of compaction on the farm; A personal view. Soil Technology, 3: 225-229.

Egyptian National Specialized Committee 2003. Urban encroachment and agricultural land loss. Report of Effective Short-term Policies.

El-Sayed, Shimaa K.H. 2009. Geographic information system for nutrient requirements in El-Fayoum district, El-Fayoum Governorate, Egypt. M. Sc. Thesis, Fac. of Agric., El-Fayoum Univ., Egypt.

El Shazly, M.M.; E.A. Hamid; A.A. Moussa and M.A. Metwally 1991. Total and chemically extractable $\mathrm{Fe}$ and $\mathrm{Mn}$ in Torrerts and Torrifluvent from Egypt. Egypt. J. Soil Sc., 31 (1): 115-130.

El-Sowfy, D.M. 2004. Studies on the status of iron in soil and plant. Ph. D. Thesis, Fac. of Agric. at El-Fayoum, Cairo Univ., Egypt.

Gee, G.W. and J.W. Bauder 1986. Particle size analysis. In: Methods of Soils Analysis, Part I, Klute, A. (Ed.), Agronomy No. 9.

Gomez, C.A. and A.A. Gomez 1983. Statistical Analysis Procedure of Agricultural Research. John Wiley and Sons, New York, pp. 25-30.

FAO 1990. Guidelines for Soil Description. $3^{\text {rd. }}$ Ed. Revised, Soil Resources, Management and Conservation Service, Land and Water Development Division, Rome Italy.

Follett, R.H. and W.L. Lindsay 1971. Changes in DTPA-extractable zinc, iron, manganese and copper in soils following fertilization. Soil Sci. Soc. Amer. Proc., 35: 600-607.

He, Z.L.; M.J. Wilson; C.O. Campbell; A.C. Edwards and S.J. Chapman 1995. Distribution of phosphorus in soil aggregate fractions and its significance with regard to phosphorus transport in agricultural runoff. Water Air Soil Pollut., 83: 69-84.

Ibrahim, Sh.B. 2001. Pedogenic aspects as related to soil fertility status at El Fayoum, Egypt. Ph. D. Thesis, Fac. of Agric. at El Fayoum, Cairo Univ., Egypt.

ILWIS GIS 2005. Integrated Land and Water Information System. Version 3.3, ITC, Enschede, The Netherlands.

Jayraman, J.(1981). Laboratory Manual in Biochemistry .Wily Eastern Limited New York .pp. 61-73.

Kamel, G.H. 2006. Phosphorus status of some soils of El-Fayoum Governorate. M. Sc. Thesis, Fac. of Agric., El-Fayoum Univ., Egypt.

Kishk, F.M.; M.N. Hassan; I. Ghanem and L. El Sissy 1973. Status of copper in some calcareous and non calcareous soils of Egypt. Plant and Soil, 39: 487-496.

Lajtha, K. and S.H. Bloomer 1988. Factors affecting phosphate sorption and phosphate retention in a desert ecosystem. Soil Sci., 146: 160-167.

Lawrence, G.P. (1977). Measurement of pore size in fine textured soils: A review of existing techniques. J. Soil Sci., 28: 527-540.

Leinweber, P.; L. Haumaier and W. Zech 1997. Sequential extractions and 31PMNR spectroscopy of phosphorus forms in animal manures, whole soils and particle size separates from a densely populated livestock area in northwest Germany. Biology and Fertility of Soils, 25: 89-94.

Lindsay, W.L. 1972. Inorganic phase equilibria of micronutrients in soils, In: Micronutrients in agriculture. Mortvedt, J.J., Giordano, P.M. and W.L. Linsday, eds.: Soil Sci. Soc. Amer., Madison, W.I., U.S.A.

Lindsay, W.L. 1991. Iron oxide solubilization by organic matter and its effect on iron availability. Plant and Soil, 130: 27-34.

Fayoum J. Agric. Res. \& Dev., Vol.24, No.2, July, 2010 
Lindsay, W.L. and W.A. Norvell 1978. Development of DTPA soil test for Zn, Fe, $\mathrm{Mn}$ and Cu. Soil Sci. Soc. Am. J., 42: 421.

Manu, A.; A. Bationo and S.C. Geiger 1991. Fertility status of selected millet producing soils of West Africa with emphasis on phosphorus. Soil Sci., 152: 315-320.

McKenzie, R.M. 1977. Manganese oxides and hydroxides, in: Minerals in the Soil Environment. Dixon, J.b. and Weed, S.B.(eds.), Soil Sci. Soc. of America, Madison, Wis., 181.

Michel, K.A.; J.K. Gillels; P.A. Hamilton and S. Freed 1956. Colorimetric Methods for determination of sugars and relate substances. Analytical Chemistry, 28(3).121-126.

Parkinson, J.A. and S.E. Allen 1975. Ewer oxidation procedure suitable for the determination of nitrogen and mineral nutrients in biological material. Commun. Soil Sci. Plant Analysis, 6: 1-11.

Rolston, D.E.; J.C. Rauschlolo; J.R. Phene; M.R. Miller; M.R. Uriu; M. Carlson and D.W. Hendrson 1979. Applying nutrients and others chemical to trickle irrigation crops. Univ. of Calif., Div. of Agric. Sci., Bull. No. 1893.

Sadik, M.K.; A.H. Abd El-Hameed and M.A. Abd Alla 2002. Evaluation of some micronutrient chemical extracts. Egypt J. Soil Sci., 42, (2): 277-297.

SPSS 2003. Statistical Package for Social Sciences, Version 12, SPSS technical Support, $h t t p: / / w w w . s p s s . c o m / t e c h /$.

Wei, X.; M. Hao; M. Shao and W.J. Gale 2006. Changes in soil properties and the availability of soil micronutrients after 18 years of cropping and fertilization. Soil \& Tillage Research, 91: 120-130.

Welburm, A.R. and H. Lichtenthaler 1984. Formulae and program to determine total carotenoids and chlorophyll $\mathrm{a}$ and $\mathrm{b}$ of leaf extracts different solvents. In: Advances Phostosynthesis Research (Sybesma, C. Ed.), 11: pp. 9-12, Mortinus Njihoff Dr W Junk Publishers, the Hague.

White, M.L. 1957. The occurrence of zinc in soil. Econ. Geol., 52: 645-651.

Zhang, M.; A.K. Alva; Y.C. Li and D.V. Calvert 1997. Fractions of iron, manganese, aluminum and phosphorus in selected sandy soils under Citrus production. Soil Sci. Soc. Amer. J., 61: 794-801.

Fayoum J. Agric. Res. \& Dev., Vol.24, No.2, July, 2010 


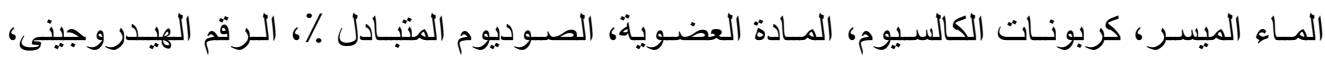

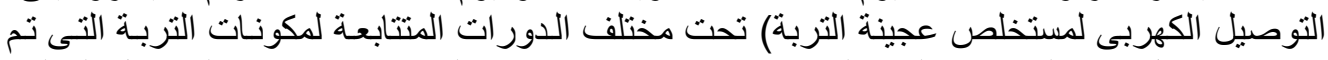

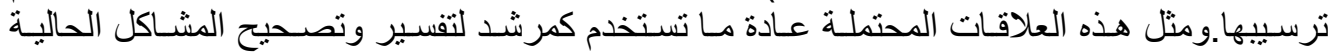

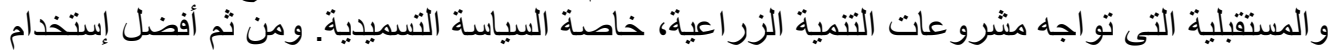

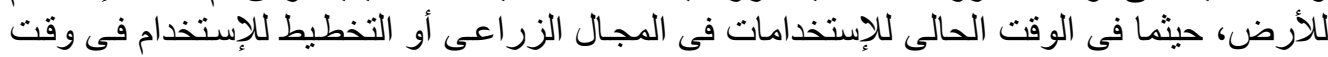

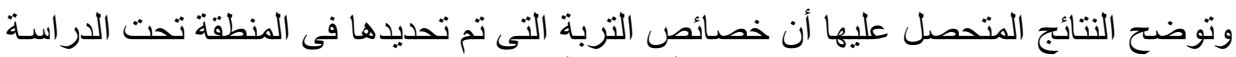

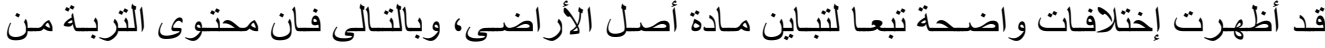

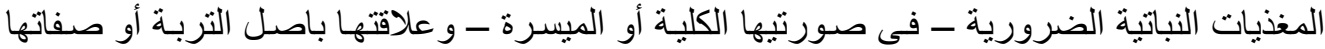

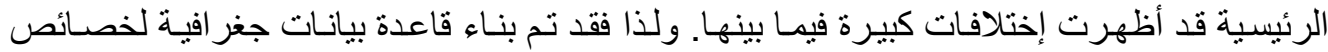

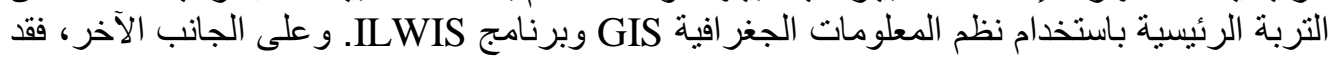

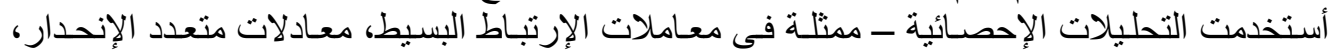

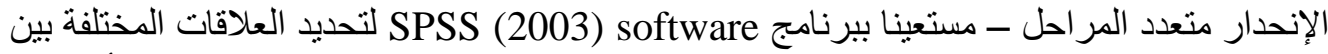

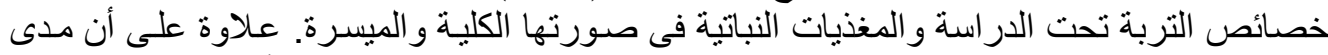

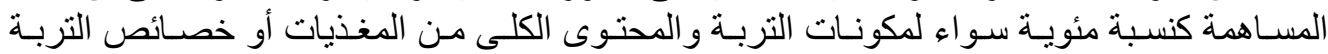
و الجزء الميسر من المغذيات قد تم تحديدهاء الإنها.

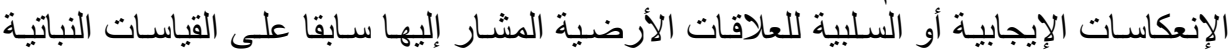

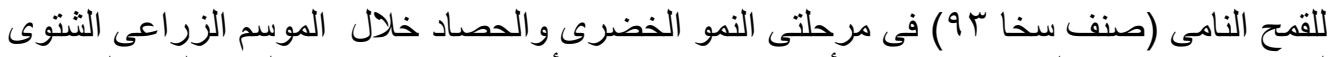

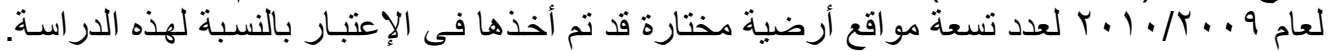

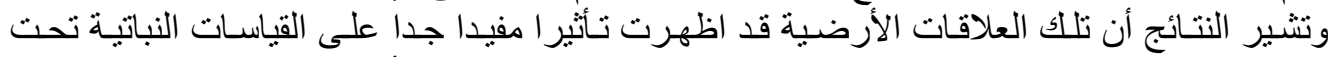

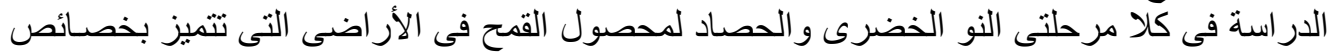

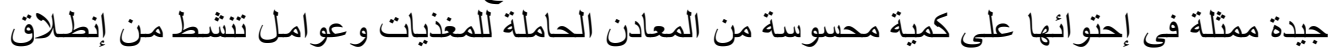

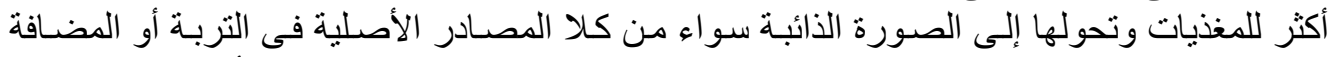

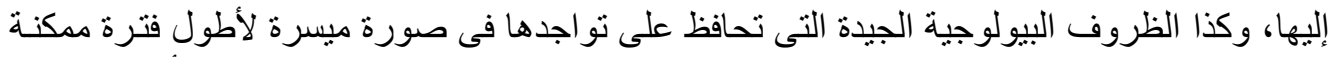

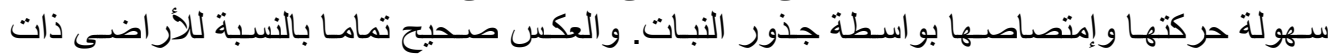

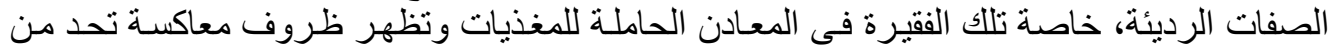
إنطلاق المغذيات وتيسر ها للإمنصاص بواسئة فاسطة جذور النبات.

$$
\text { المحكين : أ.د. السيد عبدالحى خاطر أ.د. محمود خيرى }
$$

Fayoum J. Agric. Res. \& Dev., Vol.24, No.2, July, 2010 